\title{
15. MIDDLE AMERICA NEOGENE EXPLOSIVE VOLCANISM AND ASH LAYERS: EVIDENCE FROM THE MIDDLE AMERICA TRENCH TRANSECT, DEEP SEA DRILLING PROJECT LEG 671
}

\author{
Jean-Paul Cadet, Andre Pouclet, and Yves Thisse, Département des Sciences de la Terre, \\ Université d'Orleans, 45046 Orleans, France \\ Jacques Marie Bardintzeff, Laboratoire de Petrographie-Volcanologie, Université de Paris Sud, 91405 Orsay, France \\ and \\ Jacques Azéma, Département de Geotectonique, Université Pierre et Marie Curie, 75231 Paris, France
}

\section{INTRODUCTION}

During Leg 67, the Middle-America Trench transect off Guatemala was drilled across the convergent margin of southern Mexico and Central America south of the Tehuantepec Ridge. The data of Leg 66, north of the Tehuantepec Ridge, and that of Leg 67 provided the opportunity to establish a continuous chronology of airborne volcanic ashes intercalated within the sediments (Aubouin et al., 1979; von Huene et al., 1980). Sites of both expeditions are favorably located for obtaining a good record of the explosive volcanicity of these areas, given the proximity of the volcanic sources and the position of the sites under the prevailing winds (Fig. 1).

\section{ASH AT LEG 67 SITES}

Seven sites were chosen, four on the continental margin, two in the Trench axis, and one on the Cocos Plate (Fig. 2).

Trench Slope (Sites 496, 497, 494, and 498)

(Fig. 3, Table 1, Plates 1 and 2)

Site 496 is on the upper part of the Middle America Trench slope about $47 \mathrm{~km}$ landward from the Trench axis. The uppermost unit is composed of Quaternary biogenic mud with minor volcanic glass (see Site 496 report, this volume). Light to dark gray and pale olive layers of vitric ash are common in Cores 1 to 12 and less abundant below. Almost all have been deformed into streaks and irregular blobs by drilling.

The lower sequence shows similar but semilithified sandy mudstone deposited from the Pliocene to the Miocene. Medium to dark gray ash patches and a few hard, light gray, pumiceous clasts are distributed sporadically; the biogenic mud itself typically contains $15 \%$ or less vitric ash.

Site 497 is also located on the upper part of the Trench slope a few kilometers seaward of Site 496. The section recovered is composed of monotonous hemipelagic and hemiterrigenous sediments, which can be divided into:

1) A Quaternary unit composed of mud interbedded with thin layers $(0.5-2 \mathrm{~cm})$ and patches $(1-3 \mathrm{~cm})$ of dark

\footnotetext{
${ }^{1}$ Aubouih, J., von Huene, R., et al., Init. Repts. DSDP, 67: Washington (U.S. Govt. Printing Office).
}

colored ash, deformed by drilling. Small spots (0.5-2 $\mathrm{cm}$ ) of white pale gray or olive gray ash are also present in many cores of this unit.

2) An upper Pliocene and/or Quaternary muddy unit with frequent intercalations of sandy and pebbly layers; spots or small patches of white and light gray ash appear in a few cores. Core recovery in this unit was low.

3) A lower to upper Pliocene mudstone unit with dark colored sandy layers and volcanic sand layers, a small number of which attain more than $10 \mathrm{~cm}$ thickness. White patches of vitric ash are also found in a few cores.

Vitric sands were often frozen and ashy layers effervescing, documenting the presence of gas hydrate.

Site 494 , located on the landward slope of the Middle America Trench on a small terrace, is $3 \mathrm{~km}$ from the Trench axis. The recovered lithologies are:

1) Holocene to Pliocene diatomaceous mud containing a few silt-size ash layers and ash pods rich in volcanic glass, and some fragments of light gray, hard, calcareous silty ash.

2) Lower Miocene to upper Oligocene hemipelagic clay separated from the unit above by an unconformity.

3) Middle Eocene sandy mudstone with two light gray ashy patches.

4) Middle Eocene and Upper Cretaceous mudstone resting on altered mafic and intermediate igneous rock atypical of ocean-floor basalts.

Site 498 was drilled about $3 \mathrm{~km}$ ESE (east-southeast) of Site 494 and $4 \mathrm{~km}$ from the adjacent Trench axis; Quaternary to Pliocene muds and mudstone characterize the whole section, but the poor core recovery (about $36 \%$ ) provides only scanty information about volcanic ashes limited to some patches.

\section{Trench Floor (Sites 499 and 500) (Fig. 3, Table 1)}

Two sites are located on the Trench floor-Site 499, just seaward of the Trench axis, and Site 500, at the juncture of the continental slope and Trench floor. The lithologic sequences are generally the same as at Site 495 , the oceanic reference site, but with the addition of a cover of Quaternary trench-filling turbidite. Muddy, light to dark gray ash patches and terrigenous sand layers are abundant in the trench-fill sediments, but distinct ash layers are few and restricted to Cores 1 and 13 


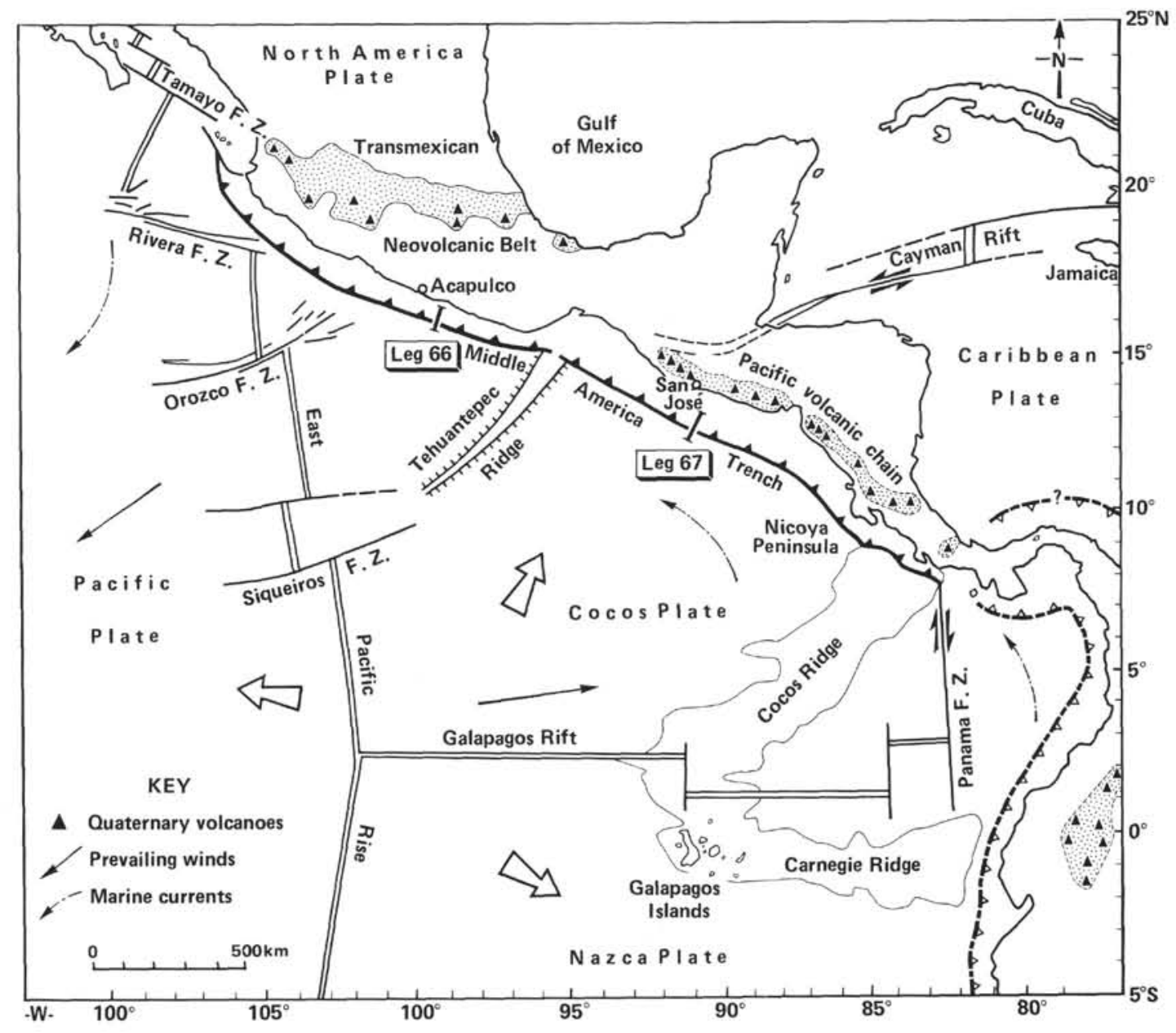

Figure 1. Geological setting of Leg 67.

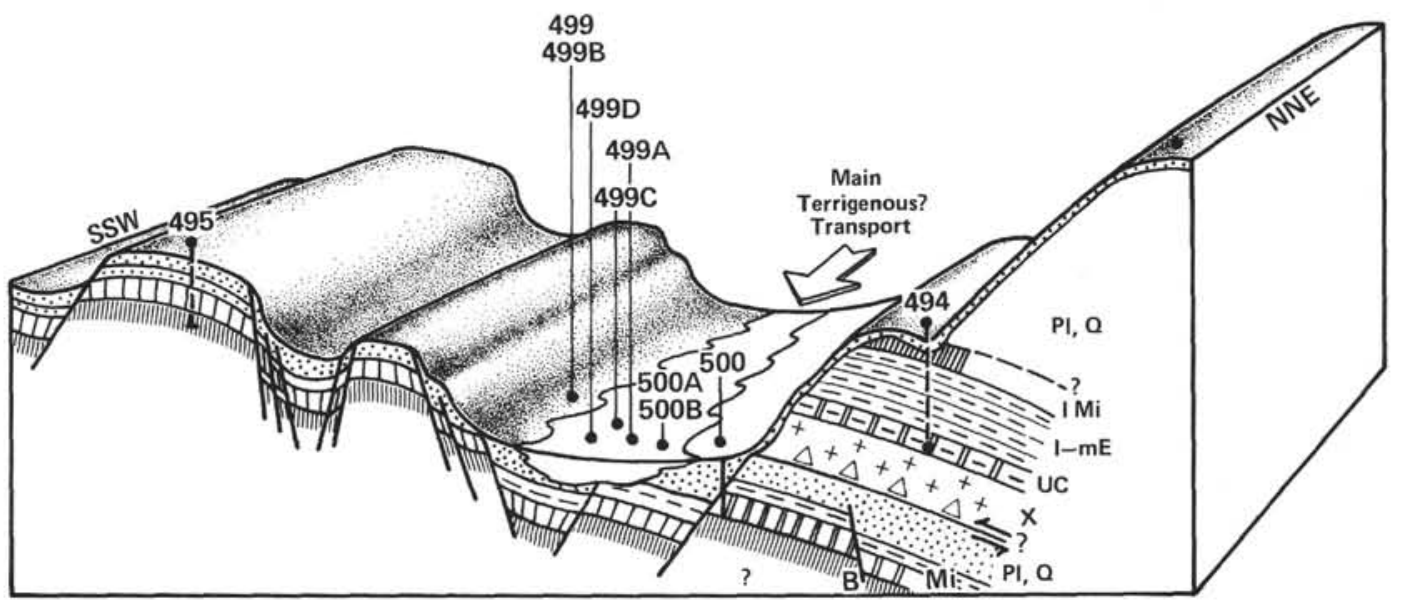

Figure 2. Schematic diagram of the subsurface geology across the Middle America Trench off Guatemala based on interpretations of Leg 67 drill samples and geophysical data from UTMSI site surveys. (Pl, Q = Pliocene and Quaternary, $\mathrm{lMi}=$ lower Miocene, $1-\mathrm{mE}=$ lower to middle Eocene, $\mathrm{UC}=$ Upper Cretaceous, $\mathrm{X}=$ undrilled section, and $\mathrm{B}=$ igneous oceanic basement.) 


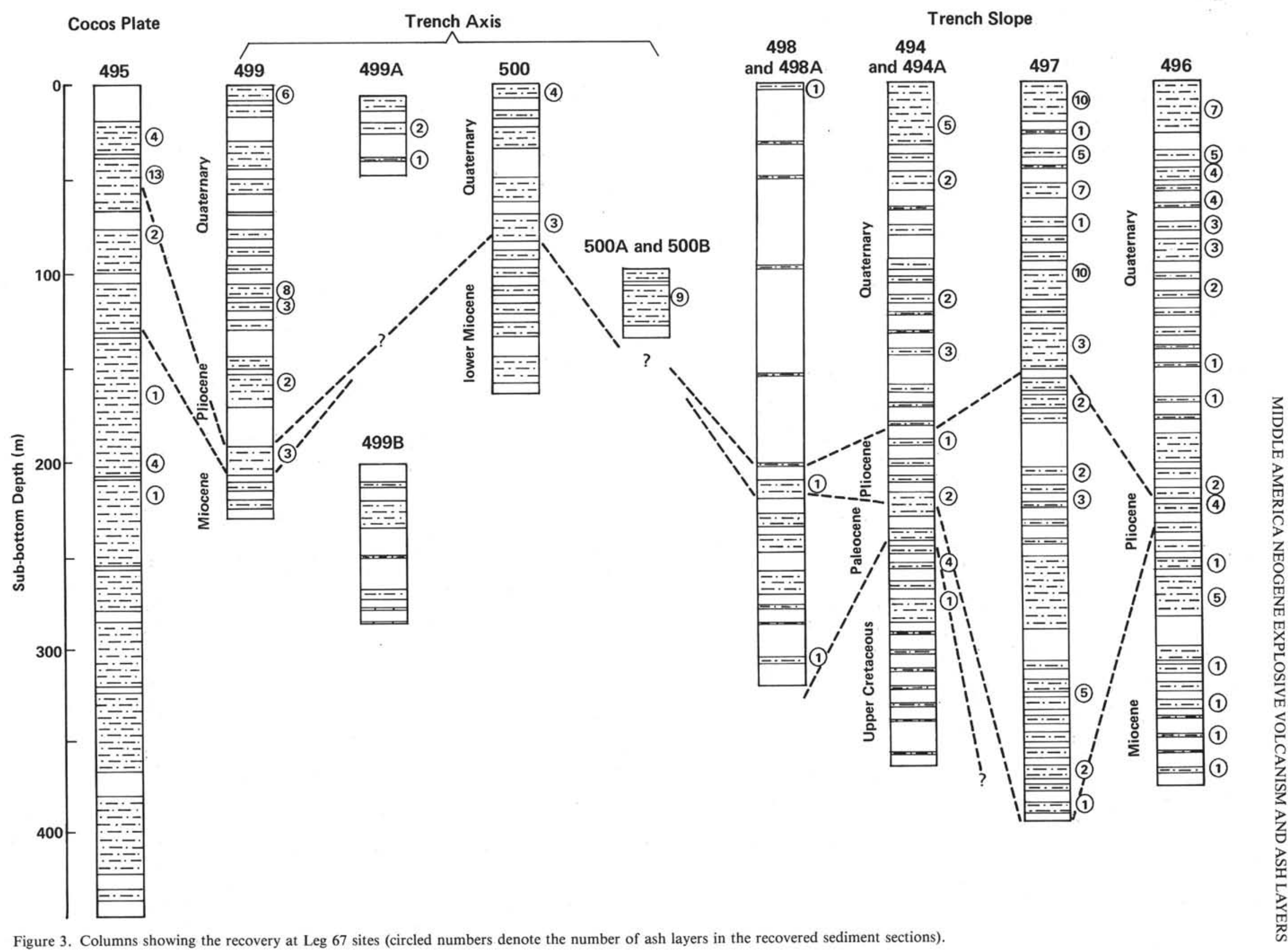


Table 1. Results of smear slides (contents in \%).

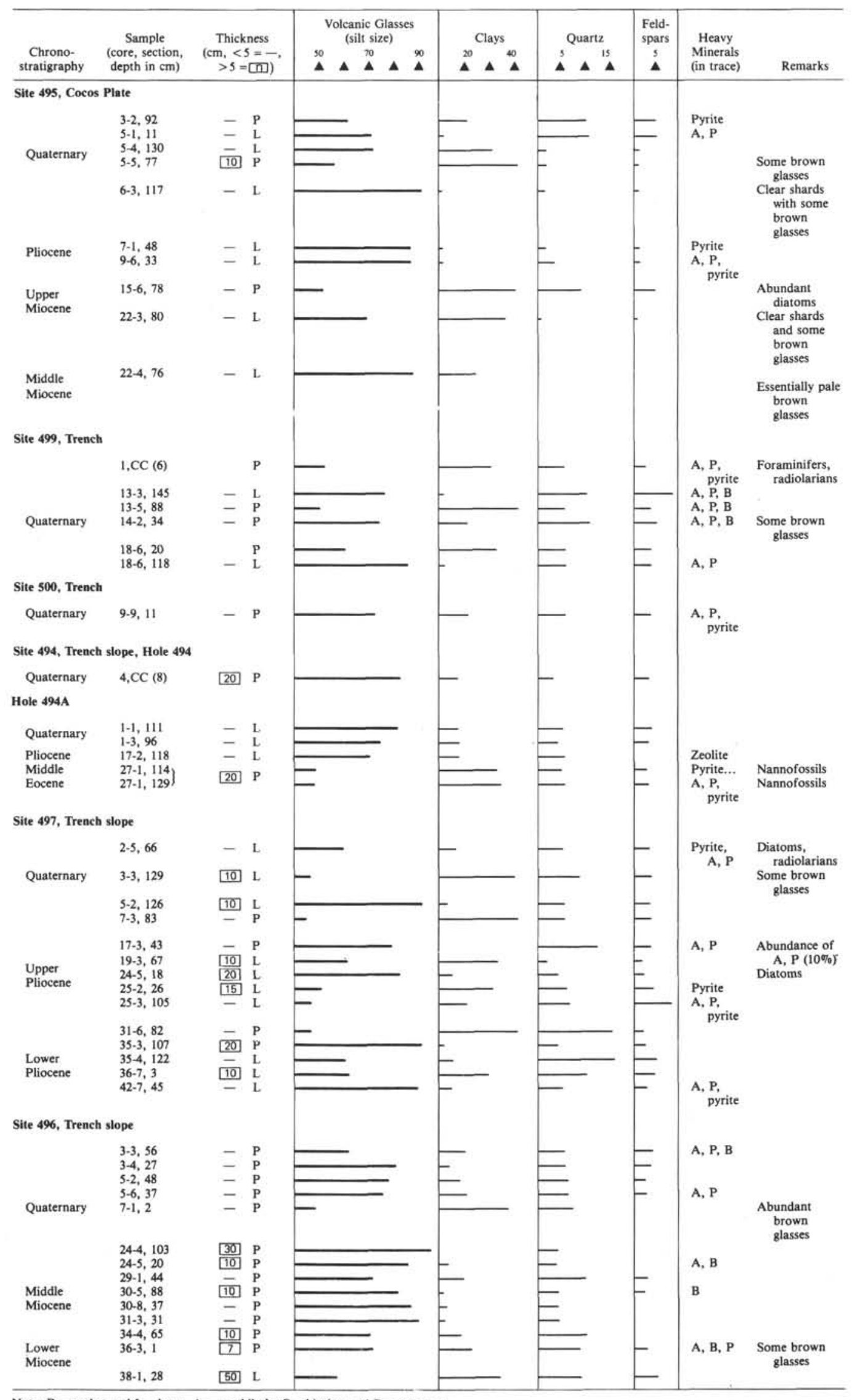

Note: $\mathrm{P}=$ pocket and $\mathrm{L}=$ layer. $\mathrm{A}=$ amphibole; $\mathrm{B}=$ biotite; and $\mathrm{P}=$ pyroxene. 
of Hole 499. Intermittent lenses and layers of volcanic ash, interbedded with siliceous hemipelagic oozes, occur through the lower Pleistocene and Pliocene (with an average of $70 \%$ volcanic glass). The remainder of the drill sequence down to basalt is devoid of ash layers.

\section{Oceanic Site 495 (Fig. 3, Table 1)}

Site 495 , on the Cocos Plate, is the oceanic reference site. The downhole sequence of sediments and rocks consists of:

1) Quaternary to upper Miocene hemipelagic diatomaceous mud with interbedded thin (less than $2-\mathrm{cm}$ thick) ash layers and patches; ashes are generally light to dark gray and silt size, averaging $70 \%$ volcanic glass ( $75 \%$ clear, smooth shards, $25 \%$ micropumice with numerous rounded or tubular vesicles and some brownish or greenish glass).

2) Middle Miocene thin, abyssal brown clay devoid of tephra.

3) Middle and lower Miocene chalky carbonate ooze with cherts changing to manganiferous chalk in the lower part, which rests on basalt. Nonbiogenic sedimentary constituents are extremely rare and usually restricted to trace amounts of zeolites or clays. These are more abundant, however, in association with thin ash layers in the upper part of the carbonate sequence.

\section{Sedimentary Environment}

The sedimentary sequence is generally free from terrigenous clastic material and is composed mostly of hemipelagic sediments in which ash falls can be preserved. However, at Sites 499 and 500 on the Trench floor, Quaternary turbidites are deposited in an energy environment that is too high to allow the individualization of ash layers after they have completed their fall through the water column.

\section{GEOCHEMISTRY AND MINERALOGY}

\section{METHOD}

For this preliminary study, 17 ash layers were sampled from the sites. Samples are glass shards of lava, lapilli, micropumice, and mineral fragments. These specimens were analyzed using a BRGM-CNRS Camebax electron-probe microanalyzer at $15-\mathrm{Kv}$ accelerating voltage, $0.02-\mu \mathrm{A}$ sample current, 10 - to $20-\mu \mathrm{m}$ average defocused beam diameter, and 10 -s count time.

\section{Glass Shards}

\section{Chemical Compositions}

Eighty-six chemical analyses for major elements were carried out. Table 2 presents the distribution of analyzed samples and assignments to six chronostratigraphic groups corresponding to periods of major volcanic activity: (1) Present, (2) upper Pleistocene, (3) Pliocene/ Pleistocene boundary, (4) lower Pliocene, (5) middle Miocene, (6) lower Miocene.

Seven analyses registered basaltic andesite close to basalt compositions (Pecerillo and Taylor, 1976) $\left(\mathrm{SiO}_{2}\right.$ between 51.8 and 56, i.e., $51.8<\mathrm{SiO}_{2}<56$ ); all of these analyses are of samples from Site 496 , on the landward side of the Trench. Seventy-nine analyses recorded
Table 2. Distribution and number of analyses of glass shards and mineral fragments.

\begin{tabular}{|c|c|c|c|c|c|}
\hline $\begin{array}{c}\text { Sample } \\
\text { (interval in } \mathrm{cm} \text { ) }\end{array}$ & $\begin{array}{l}\text { Hole } \\
496\end{array}$ & $\begin{array}{l}\text { Hole } \\
497\end{array}$ & $\begin{array}{l}\text { Hole } \\
494 \mathrm{~A}\end{array}$ & $\begin{array}{l}\text { Hole } \\
495\end{array}$ & $\begin{array}{l}\text { Chronostratigraphy } \\
\text { Group No. }\end{array}$ \\
\hline $1-1,111-113$ & & & 4-1 Pl & & \\
\hline $2-5,66-68$ & & 3-1 PI & & & Present-1 \\
\hline $3-4,27-29$ & 10 & & & & \\
\hline $5-2,48-52$ & 7-1 Pl & & & & \\
\hline $7-1,2-4$ & $7\left\{\begin{array}{l}2 \mathrm{Pl} \\
1 \mathrm{CPX}\end{array}\right.$ & & & & Upper Pleistocene-2. \\
\hline $19-4,9-10$ & $1 \mathrm{Pl}-1 \mathrm{CPX}$ & & & & \\
\hline $5-1,11-13$ & & & & $\begin{array}{c}3 \text { PI } \\
\begin{cases}1 & \text { OPX } \\
1 & \mathrm{CPX}\end{cases} \end{array}$ & \\
\hline $5-4,130-132$ & & & & $\mathrm{li} \mathrm{F}$ & Lower Pleistocene-3 \\
\hline $6-3,117-119$ & & & & 6 & \\
\hline $17-3,43-46$ & & 2-3 Pl & & & \\
\hline $\begin{array}{l}24-4,103-107 \\
7-1,11-13\end{array}$ & 1 & & & 3 & \\
\hline $\begin{array}{l}7-1,11-13 \\
17-2,118-120\end{array}$ & & & $2-1 \mathrm{CPX}$ & & Upper Pliocene-3 \\
\hline $19-3,67-69$ & & 3-1 Pl & & & \\
\hline $35-4,122-124$ & & 3-3 Pl & & & \\
\hline $36-7,3-8$ & & $\begin{cases}1 & \mathrm{Pl} \\
1 & \mathrm{CPX} \\
3 & \mathrm{Bi}\end{cases}$ & & & Lower Pliocene-4 \\
\hline $42-7,45-47$ & & 8 & & & \\
\hline $30-5,88-91$ & 8-1 PI & & & & Middle Miocene-5 \\
\hline $\begin{array}{l}31-3,31-33 \\
36-3,1-3\end{array}$ & $\begin{array}{l}9 \\
9\end{array}$ & & & & Lower Miocene-6 \\
\hline $\begin{array}{r}\text { Note: } F=\text { alkal } \\
\text { and } B i=b i \\
\text { shards anal }\end{array}$ & $\begin{array}{l}\text { feldspar; } P \\
\text { The first }\end{array}$ & $\begin{array}{l}\text { lagioc: } \\
\text { ber in } \\
\text { one th }\end{array}$ & $\begin{array}{l}\text { PXX }=0 \\
\text { phenate } \\
\text { aber of }\end{array}$ & $\begin{array}{l}\text { opyroxen } \\
\text { airs repre } \\
\text { ecific mir }\end{array}$ & $\begin{array}{l}\text { PX }=\text { clinopyroxene: } \\
\text { s the number of glass } \\
\text { s (e.g., plagioclases, }\end{array}$ \\
\hline
\end{tabular}

acid compositions ranging from dacitic to rhyolitic products $\left(65<\mathrm{SiO}_{2}<76\right)$, representing samples from all the sites.

The acid-glass analyses, irrespective of the sediment age, present a systematic deficit in the total of elements ( $\Sigma=92$ to 93$)$. Considering that there is no noticeable alteration, we attribute this deficit to hydration, in accordance with the observations of Scheidegger et al. (1978) and Fujioka et al. (1980).

Table 3 presents a large selection of different geochemical type analyses, whereas the average of acid compositions is shown in Table 4.

\section{Magmatic Affinities}

On the whole, the chemical compositions are related to calc-alkaline series. On the $\mathrm{SiO}_{2}$ /alkaline diagram, however, magmatic affinities are not very obvious, owing to the large spread of alkalines (Fig. 4).

On an AFM diagram (Fig. 5), the plots of Leg 67 analyses are distributed in the FeO-rich part of the Central American lavas area (Woodruff et al., 1979)-i.e., the composition of the glassy magmatic inclusions in phenocrysts (according to data collected by Rose et al. [1978] and Bardintzeff et al. [1980] [see the G sector of Fig. 5]. The whole rock analyses, on the other hand, are $\mathrm{MgO}$ richer (L sector of Fig. 5).

The differentiation index (DI) of Thornton and Tutthe (1960) varies from 30 to 45 in basic lavas, and from 65 to 86 in acid lavas (Table 3). As it concerns liquid phase analyses (glass fragments), this index usually appears higher than in corresponding solid-phase analyses (volcanic rocks); moreover, there is a lack of intermediate types.

We have plotted our 86 analyses on a $\mathrm{SiO}_{2} / \mathrm{K}_{2} \mathrm{O}$ diagram and compared them with the typological boundaries of Pecerillo and Taylor (1976) (Fig. 6). The dia- 
Table 3. Microprobe analyses of glass shards (54).

\begin{tabular}{|c|c|c|c|c|c|c|c|c|c|c|c|c|c|c|c|c|c|c|}
\hline \multirow{2}{*}{$\begin{array}{l}\text { Sample } \\
\text { (interval in cm) } \\
\text { Chronostrati- } \\
\text { graphic Group }\end{array}$} & \multicolumn{5}{|c|}{$\begin{array}{c}496-3-4 \\
27-29\end{array}$} & \multicolumn{4}{|c|}{$\begin{array}{c}496-5-2 \\
48-52\end{array}$} & \multicolumn{7}{|c|}{$\begin{array}{c}496-7-1, \\
2-4\end{array}$} & \multirow{2}{*}{$\frac{\begin{array}{c}496-24-4 \\
103-107\end{array}}{3}$} & \multirow{2}{*}{$\begin{array}{c}496-30-5, \\
88-91 \\
5\end{array}$} \\
\hline & & & 1 & & & & & & & & 2 & & & & & & & \\
\hline Type & $\mathrm{Rh}$ & $\mathrm{Rh}$ & $\mathrm{Rh}$ & $\mathrm{Rh}$ & $\mathrm{Rh}$ & $\mathrm{Rh}$ & $\mathrm{Rh}$ & $\mathrm{Rh}$ & $\mathrm{Rh}$ & B-An & B-An & B-An & B-An & B-An & B-An & B-An & Rh-Dc & $\mathrm{Rh}$ \\
\hline $\begin{array}{l}\text { Series } \\
\text { Analysis }\end{array}$ & $\mathrm{BA}$ & B & B & B & BC & $\mathrm{BA}$ & B & $\mathrm{p}$ & BC & $\mathrm{R}$ & B & 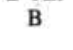 & D & B & B & $\mathrm{B}$ & B & B \\
\hline Number & 8 & 3 & 9 & 10 & 1 & 14 & 17 & 11 & 12 & 19 & 18 & 22 & 21 & 23 & 20 & 24 & 25 & 27 \\
\hline $\mathrm{SiO}_{2}$ & 74.26 & 73.57 & 73.39 & 73.77 & 72.72 & 74.66 & 74.00 & 74.10 & 73.83 & 51.81 & 54.84 & 52.64 & 52.63 & 54.96 & 54.87 & 55.91 & 70.35 & 72.82 \\
\hline $\mathrm{Al}_{2} \mathrm{O}_{3}$ & 12.73 & 12.84 & 12.77 & 12.86 & 12.89 & 12.75 & 12.46 & 12.52 & 13.00 & 13.59 & 12.99 & 13.49 & 13.12 & 14.78 & 15.48 & 15.37 & 13.95 & 12.98 \\
\hline $\mathrm{FeO} *$ & 0.53 & 0.61 & 0.66 & 0.64 & 0.64 & 0.84 & 0.60 & 0.66 & 0.94 & 13.05 & 13.63 & 13.40 & 14.35 & 12.39 & 11.12 & 11.00 & 2.10 & 0.81 \\
\hline $\mathrm{MnO}$ & 0.06 & 0.11 & 0.14 & 0.07 & 0.01 & 0.15 & 0.20 & 0.19 & 0.09 & 0.21 & 0.31 & 0.25 & 0.19 & 0.33 & 0.07 & 0.26 & 0.01 & 0.01 \\
\hline $\mathrm{MgO}$ & 0.07 & 0.08 & 0.06 & 0.06 & 0.05 & 0.07 & 0.06 & 0.08 & 0.04 & 4.62 & 3.69 & 4.27 & 4.14 & 3.73 & 3.49 & 2.07 & 0.38 & 0.13 \\
\hline $\mathrm{CaO}$ & 0.41 & 0.39 & 0.36 & 0.37 & 0.32 & 0.36 & 0.38 & 0.32 & 0.38 & 9.16 & 7.85 & 8.68 & 8.22 & 7.52 & 7.68 & 7.14 & 1.37 & 0.93 \\
\hline $\mathrm{Na}_{2} \mathrm{O}$ & 1.58 & 1.85 & 2.01 & 2.74 & 3.38 & 1.66 & 2.06 & 2.35 & 1.88 & 2.69 & 1.62 & 3.07 & 2.98 & 2.16 & 3.39 & 3.77 & 1.51 & 1.37 \\
\hline $\mathrm{K}_{2} \mathrm{O}$ & 2.33 & 2.68 & 3.03 & 2.70 & 2.62 & 2.21 & 2.49 & 2.59 & 3.19 & 1.35 & 1.57 & 1.27 & 1.46 & 1.42 & 1.22 & 1.36 & 1.79 & 2.82 \\
\hline $\mathrm{TiO}_{2}$ & 0.10 & 0.08 & 0.09 & 0.05 & 0.01 & 0.00 & 0.05 & 0.02 & 0.00 & 1.11 & 1.23 & 1.24 & 1.21 & 0.98 & 0.99 & 1.14 & 0.46 & 0.10 \\
\hline Total & 92.07 & 92.22 & 92.51 & 93.25 & 92.64 & 92.71 & 92.31 & 92.83 & 93.36 & 97.60 & 97.72 & 98.32 & 98.29 & 98.27 & 98.30 & 98.00 & 91.92 & 91.95 \\
\hline $\mathrm{Q}$ & 54.76 & 51.07 & 48.65 & 46.08 & 41.77 & 54.85 & 50.97 & 49.03 & 48.96 & - & 9.71 & - & - & 7.76 & 3.42 & 5.00 & 49.81 & 51.27 \\
\hline Or & 13.78 & 15.85 & 17.92 & 15.97 & 15.50 & 13.07 & 14.73 & 15.32 & 18.87 & 7.99 & 9.29 & 7.51 & 8.64 & 8.40 & 7.22 & 8.04 & 10.59 & 16.68 \\
\hline $\mathrm{Ab}$ & 13.35 & 15.64 & 16.99 & 23.16 & 28.57 & 14.03 & 17.41 & 19.86 & 15.89 & 22.73 & 13.69 & 25.95 & 25.19 & 18.26 & 28.65 & 31.86 & 12.76 & 11.58 \\
\hline An & 2.04 & 1.94 & 1.79 & 1.84 & 1.59 & 1.79 & 1.89 & 1.59 & 1.89 & 20.99 & 23.50 & 19.25 & 18.08 & 26.40 & 23.38 & 20.96 & 6.80 & 4.62 \\
\hline Cor & 6.86 & 6.18 & 5.52 & 4.75 & 3.90 & 6.97 & 5.68 & 5.26 & 5.75 & - & - & - & - & - & - & - & 7.03 & 5.97 \\
\hline (Wo & - & - & - & - & - & - & - & - & - & 10.22 & 6.46 & 9.95 & 9.48 & 4.56 & 6.15 & 6.04 & - & - \\
\hline Di\{En & - & - & - & - & - & - & - & - & - & 3.56 & 1.90 & 3.26 & 2.91 & 1.42 & 2.01 & 1.39 & - & - \\
\hline$T_{F s}$ & - & - & - & - & - & - & - & - & - & 6.93 & 4.84 & 7.02 & 6.94 & 3.31 & 4.35 & 5.04 & - & - \\
\hline En & 0.17 & 0.20 & 0.15 & 0.15 & 0.13 & 0.17 & 0.15 & 0.20 & 0.10 & 7.35 & 7.33 & 6.96 & 6.97 & 7.90 & 6.72 & 3.79 & 0.95 & 0.32 \\
\hline Fs & 0.92 & 1.19 & 1.32 & 1.22 & 1.18 & 1.82 & 1.39 & 1.53 & 1.89 & 14.31 & 18.69 & 14.99 & 16.60 & 18.40 & 14.53 & 13.73 & 3.11 & 1.34 \\
\hline Ol Fo & - & - & - & - & - & - & - & - & - & 0.45 & - & 0.32 & 0.33 & - & - & - & - & - \\
\hline $\mathrm{Fa}$ & - & - & - & - & - & - & - & - & - & 0.96 & - & 0.75 & 0.86 & - & - & - & - & - \\
\hline II & 0.19 & 0.15 & 0.17 & 0.09 & 0.02 & - & 0.09 & 0.04 & - & 2.11 & 2.34 & 2.36 & 2.30 & 1.86 & 1.88 & 2.17 & 0.87 & 0.19 \\
\hline DI & 81.89 & 82.56 & 83.56 & 85.21 & 85.84 & 81.95 & 83.11 & 84.21 & 83.72 & 30.72 & 32.69 & 33.46 & 33.83 & 34.42 & 39.29 & 44.90 & 73.16 & 79.53 \\
\hline
\end{tabular}

Note: Total Fe as FeO*. See Table 2 and text for identification of chronostratigraphic groups. $\mathrm{DI}=$ differentiation index. $\mathrm{B}-\mathrm{An}=$ basaltic andesite; $\mathrm{Dc}=$ dacite, Dc-A $=$ dacitic andesite; $\mathrm{Rh}=$ rhyolite, and $\mathrm{Rh}-\mathrm{Dc}=$ rhyo-dacite. Series $\mathrm{A}=$ low $\mathrm{K}, \mathrm{B}=$ medium $\mathrm{K}$, and $\mathrm{C}=$ high $\mathrm{K}$; intermediate points are indicated by combinations (e.g., $\mathrm{BA}, \mathrm{BC}$, and so on).

gram is further subdivided to indicate a supplementary distinction of the rhyo-dacites $\left(70<\mathrm{SiO}_{2}<72\right)$ within the rhyolite field.

Basic lavas are calc-alkaline basalts and mediumpotassic andesites. As for acid lavas, $\mathrm{K}_{2} \mathrm{O}$ correlated with $\mathrm{SiO}_{2}$ shows an important spread in two directions -positively or negatively. This spread may be due to analytical method, to variations in hydration and alteration, or to magmatic differentiation and diversity of products coming from distinct volcanoes. Glass fragments have the same size and have probably been submitted to the same hydration rate during deposition, moreover there is no simple, systematic relation of location, age, and chemical composition. Thus nonmagmatic variation factors are probably of secondary importance.

$\mathrm{SiO}_{2} / \mathrm{K}_{2} \mathrm{O}$ positive correlation is perhaps due to differentiation by fractional crystallization. Calc-alkaline basalts are differentiated into basaltic-andesites, andesites, dacites, rhyo-dacites, and rhyolites. Negative correlation shows variations in potassic alkalinity during each period of activity; consequently, it may correspond to products from different magmatic series, if we consider that possible diffusion of $\mathrm{K}_{2} \mathrm{O}$, due to submarine alteration, is less important than original variation. In this hypothesis, supported by the lack of time correlation, we schematically separate acidic lavas into three categories: (A) low potassium, (B) medium potassium, and $(C)$ high potassium. For the position of the boundaries, we refer to similar data from Leg 66 (Cadet et al., in press).

\section{Statistical Studies}

In order to benefit from previous observations we took a multidimensional statistical approach concerning lavas. The method is the principal component analysis of $n$ samples and $p$ variables, in this case chemical analyses (Lebart et al., 1979). New variables, or factors correlated with the axis of the dispersion ellipse, are extracted from the correlation matrix and computed as linear transformations. These factors are arranged according to their decreasing respective contribution to the dispersion (whole variance of the population). The first main factors are used to visualize the dispersion of samples on an orthogonal projection. The basic lavas are considered as anonymous samples. Results are shown on Table 5.

The first three factors explain $82.33 \%$ of the variance, a very satisfying score considering the heterogeneities in the age and origin of the samples. The first factor opposes $\mathrm{SiO}_{2}$ to $\mathrm{FeO}, \mathrm{MgO}, \mathrm{TiO}_{2}$, and $\mathrm{Al}_{2} \mathrm{O}_{3}$. It expresses differentiation, which is confirmed by the position of basic lavas (indicated by Bs and An-Bs on the Fig. 7 inset). Rhyolites, rhyodacites, dacites, andesites, and basalts are spread according to the F1 factor on the F1/F2 diagram (Fig. 7).

The F2 factor opposes alkaline elements and alumina to other elements. It expresses the distinction between the three magnetic groups A, B, and C (derived in Fig. 6 ), while defining the combined role of $\mathrm{K}_{2} \mathrm{O}, \mathrm{Na}_{2} \mathrm{O}$, and $\mathrm{Al}_{2} \mathrm{O}_{3}$. Thus the schematic division of $\mathrm{A}, \mathrm{B}$, and $\mathrm{C}$ areas corresponds to different series, with increasing calc-al- 
Table 3. (Continued).

\begin{tabular}{|c|c|c|c|c|c|c|c|c|c|c|c|c|c|c|c|c|c|c|c|}
\hline \multicolumn{3}{|c|}{$\begin{array}{c}496-30-5 \\
88-91\end{array}$} & \multicolumn{4}{|c|}{$\begin{array}{c}496-31-3, \\
31-33\end{array}$} & \multicolumn{5}{|c|}{$\begin{array}{c}496-36-3 \\
1-3\end{array}$} & \multirow{2}{*}{\multicolumn{2}{|c|}{$\begin{array}{c}\begin{array}{c}497-2-5 \\
66-68\end{array} \\
1\end{array}$}} & $\begin{array}{c}497-17-3, \\
43-46 \\
\end{array}$ & \multirow{2}{*}{\multicolumn{3}{|c|}{$\begin{array}{c}497-19-3, \\
67-69 \\
3 \\
\end{array}$}} & \multicolumn{2}{|c|}{$\begin{array}{r}497-35-4 \\
122-124 \\
\end{array}$} \\
\hline \multicolumn{7}{|c|}{5} & \multicolumn{5}{|c|}{6} & & & & & & & & \\
\hline $\mathrm{Rh}$ & $\mathrm{Rh}$ & $\mathrm{Rh}$ & $\mathrm{Rh}$ & $\mathrm{Rh}$ & $\mathrm{Rh}$ & $\mathrm{Rh}$ & $\mathrm{Rh}$ & $\mathrm{Rh}$ & $\mathrm{Rh}$ & $\mathrm{Rh}$ & $\mathrm{Rh}$ & Rh-Dc & $\mathrm{Rh}-\mathrm{Dc}$ & Rh & $\mathrm{Rh}$ & $\mathrm{Dc}-\mathrm{A}$ & $\mathrm{Dc}$ & $\mathrm{Dc}$ & Dc \\
\hline B & C & C & A & A & BA & B & A & A & A & A & $\mathrm{AB}$ & C & C & BC & A & C & C & C & C \\
\hline 29 & 26 & 32 & 40 & 35 & 38 & 37 & 44 & 46 & 43 & 49 & 48 & 53 & 52 & 55 & 58 & 57 & 59 & 62 & 61 \\
\hline 74.68 & 72.99 & 72.81 & 74.66 & 75.91 & 74.59 & 74.77 & 75.23 & 74.01 & 74.79 & 75.30 & 75.59 & 71.11 & 71.52 & 73.09 & 73.01 & 65.12 & 69.49 & 66.12 & 66.50 \\
\hline 13.46 & 13.88 & 13.65 & 11.38 & 11.58 & 11.57 & 11.59 & 11.36 & 11.35 & 11.47 & 11.27 & 11.49 & 14.07 & & 12.28 & 12.58 & 15.57 & 13.63 & 15.36 & 15.81 \\
\hline 0.70 & 1.09 & 0.89 & 0.97 & 1.19 & 1.25 & 1.18 & 0.99 & 1.19 & 1.03 & 0.95 & 0.99 & 1.55 & 1. & 0.79 & 1.44 & 4.09 & 3.09 & 2.69 & 1.68 \\
\hline 0.03 & 0.00 & 0.09 & 0.08 & 0.01 & 0.17 & 0.00 & 0.11 & 0.11 & 0.03 & 0.00 & 0.0 & 0.00 & 0.0 & 0.00 & 0.00 & 0.16 & 0.07 & 0.08 & 0.02 \\
\hline 0.07 & 0.21 & 0.21 & 0.14 & 0.13 & 0.13 & 0.16 & 0.19 & 0.20 & 0.18 & 0.14 & 0.1 & 0.20 & 0.1 & 0.12 & 0.36 & 1.07 & 0.34 & 0.60 & 0.55 \\
\hline 1.16 & 0.57 & 0.57 & 0.81 & 0.76 & 0.86 & 0.82 & 0.97 & 0.98 & 0.99 & 0.94 & 0.85 & 1.14 & 1.0 & 0.93 & 1.66 & 2.60 & 1.06 & 1.54 & 1.68 \\
\hline 3.13 & 2.30 & 2.43 & 0.81 & 1.09 & 2.08 & 1.43 & 1.33 & 1.59 & 2.20 & 1.80 & 1. & 2.41 & 2. & 1. & 2.12 & 2.42 & 2.87 & 2.33 & 2.36 \\
\hline 2.45 & 3.27 & 3.80 & 2.50 & 2.38 & 2.49 & 2.55 & 1.59 & 2.36 & 1.63 & 1.97 & 2.52 & 2.70 & 3.10 & 3.89 & 1.07 & 1.72 & 2.34 & 1.68 & 1.89 \\
\hline 0.20 & 0.12 & 0.15 & 0.14 & 0.28 & 0.17 & 0.21 & 0.20 & 0.22 & 0.15 & 0.21 & 0.17 & 0.17 & 0.02 & 0.15 & 0.29 & 0.64 & 0.60 & 0.39 & 0.39 \\
\hline 95.86 & 94.44 & 94.59 & 91.48 & 93.33 & 93.21 & 92.70 & 91.98 & 92.00 & 92.47 & 92.60 & 93.30 & 93.36 & 93.15 & 93.19 & 92.54 & 93.39 & 93.48 & 90.80 & 91.55 \\
\hline 44.07 & 44.76 & 41.91 & 57.67 & 57.85 & 49.88 & 53.88 & 58.29 & 52.42 & 52.73 & 54.45 & 54.34 & 42.87 & 42.91 & 44.27 & 51.52 & 34.24 & 38.90 & 39.94 & 40.01 \\
\hline 14.49 & 19.34 & 22.48 & 14.79 & 14.08 & 14.73 & & 9.40 & 13.96 & 9.64 & 11.65 & 14 & & & & 6.33 & 10.17 & 4 & 9.94 & 11.18 \\
\hline 26.45 & 19.44 & 20.54 & 6.85 & 9.21 & 17.58 & 12.09 & 11.24 & 13.44 & 18.59 & 15.21 & 12.85 & 20.37 & 18. & 16.3 & 17.92 & 20.45 & 24.26 & 19.69 & 19.95 \\
\hline 5.76 & 2.83 & 2.83 & 4.02 & 3.77 & 4.27 & 4.07 & 4.82 & 4.86 & 4.91 & 4.67 & 4.22 & 5.6 & $5 .($ & 4.62 & 8.24 & 12.91 & 5.26 & 7.64 & 8.34 \\
\hline 3.54 & 5.51 & 4.49 & 5.86 & 5.82 & 3.78 & 4.98 & 5.68 & 4.39 & 4.28 & 4.46 & 4.71 & 5.10 & 4.6 & 3.19 & 4.91 & 4.99 & 4.44 & 6.90 & 6.82 \\
\hline- & - & - & - & - & - & - & - & - & - & - & - & - & - & - & - & - & - & - & - \\
\hline- & - & - & - & - & - & - & - & - & - & - & - & - & - & - & - & - & - & - & - \\
\hline- & - & - & - & - & - & - & - & - & - & - & - & - & - & - & - & - & - & - & - \\
\hline 0.17 & 0.52 & 0.52 & 0.35 & 0.32 & 0.32 & 0.40 & 0.47 & 0.50 & 0.25 & 0.35 & 0.40 & 0.50 & 0.40 & 0.30 & 0.90 & 2.67 & 0.85 & 1.50 & 1.38 \\
\hline 1.01 & 1.80 & 1.55 & 1.70 & 1.74 & 2.33 & 1.82 & 1.69 & 2.02 & 1.70 & 1.40 & 1.57 & 2.56 & 2.86 & 1.20 & 2.16 & 6.74 & 4.81 & 4.44 & 2.47 \\
\hline- & - & - & - & - & - & - & - & - & - & - & - & - & - & - & - & - & - & - & - \\
\hline$\overline{0.38}$ & $\overline{023}$ & $\overline{0.28}$ & $\overline{0.77}$ & $\overline{0.53}$ & $\overline{0}$ & $\overline{0}$ & $\overline{0.38}$ & $\overline{0}$ & $\overline{0}$ & $\overline{0}$ & $\overline{-1}$ & $\overline{3}$ & $\overline{0}$ & $\overline{0}$ & $\overline{0.58}$ & - & - & $\overline{0} 74$ & $\overline{0}$ \\
\hline 0.38 & 0.23 & 0.28 & 0.27 & 0.53 & 0.32 & 0.40 & 0.38 & 0.42 & 0.28 & 0.40 & 0.32 & 0.32 & 0.04 & 0.28 & 0.55 & 1.22 & 1.14 & 0.74 & 0.74 \\
\hline 85.01 & 83.54 & 84.93 & 79.31 & 81.14 & 82.19 & 81.05 & 78.93 & 79.82 & 80.96 & 81.31 & 82.10 & 79.21 & 80.18 & 83.59 & 75.77 & 64.86 & 77.00 & 69.57 & 71.14 \\
\hline
\end{tabular}

Table 3. (continued).

\begin{tabular}{|c|c|c|c|c|c|c|c|c|c|c|c|c|c|c|c|c|}
\hline \multirow{2}{*}{$\begin{array}{l}\text { Sample } \\
\text { (interval in cm) } \\
\text { Chronostrati- } \\
\text { graphic Group }\end{array}$} & \multicolumn{4}{|c|}{$\begin{array}{c}497-42-7 \\
45-47\end{array}$} & \multicolumn{3}{|c|}{$\begin{array}{c}494 \mathrm{~A}-1-1 \\
111-113\end{array}$} & \multicolumn{2}{|c|}{$\begin{array}{c}494 A-17-2 \\
118-120 \\
\end{array}$} & \multirow[t]{2}{*}{$\begin{array}{c}495-5-1 \\
11-13 \\
\end{array}$} & \multicolumn{3}{|c|}{$\begin{array}{l}495-6-3 \\
117-119\end{array}$} & \multicolumn{3}{|c|}{$\begin{array}{c}495-7-1 \\
48-50\end{array}$} \\
\hline & \multicolumn{2}{|c|}{4} & \multirow[b]{2}{*}{$\mathrm{Rh}$} & \multirow{3}{*}{$\begin{array}{l}\mathrm{Rh} \\
\mathrm{AB}\end{array}$} & \multicolumn{3}{|c|}{1} & \multirow{3}{*}{$\begin{array}{c}\text { Rh } \\
\text { C }\end{array}$} & \multirow{3}{*}{ Rh } & & \multicolumn{3}{|c|}{3} & \multirow{4}{*}{$\begin{array}{l}\text { Rh } \\
\text { BA }\end{array}$} & \multirow{4}{*}{$\begin{array}{l}\mathrm{Rh} \\
\mathrm{BC}\end{array}$} & \multirow{4}{*}{$\begin{array}{c}\text { Rh } \\
\text { C }\end{array}$} \\
\hline Type & $\mathbf{R h}$ & $\mathrm{Rh}$ & & & Rh-Dc & $\mathrm{Rh}$ & Dc & & & \multirow{2}{*}{$\begin{array}{c}\text { Rh } \\
\text { C }\end{array}$} & $\mathrm{Rh}-\mathrm{Dc}$ & Rh & Rh-Dc & & & \\
\hline Series & A & A & A & & B & B & C & & & & B & B & $\mathrm{CB}$ & & & \\
\hline Analysis & & & & & & & & & & & & & & & & \\
\hline Number & 66 & 64 & 65 & 68 & 74 & 71 & 72 & 76 & 75 & 77 & 81 & 80 & 83 & 85 & 86 & 84 \\
\hline $\mathrm{SiO}_{2}$ & 73.28 & 75.32 & 73.37 & 73.72 & 71.14 & 74.32 & 68.39 & 71.34 & 71.55 & 71.15 & 70.60 & 72.60 & 70.63 & 73.31 & 73.06 & 72.84 \\
\hline $\mathrm{Al}_{2} \mathrm{O}_{3}$ & 12.22 & 12.05 & 12.48 & 12.47 & 12.87 & 12.71 & 15.36 & 13.46 & 13.29 & 13.14 & 13.08 & 13.41 & 13.28 & 12.23 & 13.10 & 13.46 \\
\hline $\mathrm{FeO}^{\circ}$ & 1.21 & 0.74 & 1.23 & 1.08 & 1.97 & 0.90 & 3.36 & 1.31 & 1.27 & 1.28 & 1.59 & 1.70 & 1.49 & 0.74 & 0.88 & 0.91 \\
\hline $\mathrm{MnO}$ & 0.02 & 0.00 & 0.00 & 0.00 & 0.00 & 0.00 & 0.06 & 0.04 & 0.00 & 0.05 & 0.02 & 0.03 & 0.00 & 0.08 & 0.03 & 0.17 \\
\hline $\mathrm{MgO}$ & 0.18 & 0.13 & 0.17 & 0.22 & 0.29 & 0.12 & 0.52 & 0.17 & 0.17 & 0.24 & 0.26 & 0.30 & 0.27 & 0.13 & 0.14 & 0.11 \\
\hline $\mathrm{CaO}$ & 1.05 & 0.91 & 1.07 & 1.19 & 1.40 & 0.85 & 2.03 & 0.77 & 0.67 & 1.20 & 0.88 & 0.99 & 0.87 & 0.85 & 0.65 & 0.77 \\
\hline $\mathrm{Na}_{2} \mathrm{O}$ & 1.56 & 2.30 & 1.94 & 2.45 & 1.73 & 2.95 & 3.71 & 2.27 & 2.20 & 2.48 & 2.32 & 1.93 & 3.36 & 1.82 & 2.07 & 2.26 \\
\hline $\mathrm{K}_{2} \mathrm{O}$ & 1.43 & 1.79 & 1.55 & 1.54 & 2.10 & 2.90 & 3.21 & 3.37 & 3.35 & 3.49 & 2.21 & 2.16 & 2.52 & 2.05 & 3.05 & 3.25 \\
\hline $\mathrm{TiO}_{2}$ & 0.12 & 0.09 & 0.07 & 0.11 & 0.23 & 0.12 & 0.52 & 0.24 & 0.29 & 0.21 & 0.22 & 0.24 & 0.27 & 0.02 & 0.18 & 0.21 \\
\hline Total & 91.08 & 93.34 & 91.87 & 92.78 & 91.72 & 94.89 & 97.16 & 92.97 & 92.80 & 93.24 & 91.18 & 93.35 & 92.69 & 91.24 & 93.15 & 93.98 \\
\hline Q & 55.29 & 52.42 & 52.65 & 49.90 & 48.15 & 43.42 & 26.96 & 42.40 & 43.41 & 39.50 & 45.21 & 49.29 & 38.16 & 52.21 & 47.13 & 44.71 \\
\hline Or & 8.46 & 10.59 & 9.17 & 9.11 & 12.42 & 17.15 & 18.99 & 19.93 & 19.81 & 20.64 & 13.07 & 12.78 & 14.91 & 12.13 & 18.04 & 19.22 \\
\hline $\mathrm{Ab}$ & 13.18 & 19.44 & 16.40 & 20.71 & 14.62 & 24.93 & 31.36 & 19.19 & 18.59 & 20.96 & 19.61 & 16.31 & 28.40 & 15.38 & 17.49 & 19.10 \\
\hline An & 5.21 & 4.52 & 5.31 & 5.91 & 6.95 & 4.22 & 10.08 & 3.82 & 3.33 & 5.96 & 4.37 & 4.91 & 4.32 & 4.22 & 3.23 & 3.82 \\
\hline Cor & 6.19 & 4.67 & 5.66 & 4.60 & 5.20 & 3.16 & 2.08 & 4.67 & 4.82 & 3.09 & 5.26 & 6.09 & 3.43 & 5.46 & 5.20 & 4.81 \\
\hline $\int_{0}^{\text {Wo }}$ & - & - & - & - & - & - & - & - & - & - & - & - & - & - & - & - \\
\hline Di $\{$ En & - & - & - & - & - & - & - & - & - & - & - & - & - & - & - & - \\
\hline IFs & - & - & - & - & - & - & - & - & - & - & - & - & - & - & - & - \\
\hline En & 0.45 & 0.32 & 0.42 & 0.55 & 0.72 & 0.30 & 1.30 & 0.42 & 0.42 & 0.60 & 0.65 & 0.75 & 0.67 & 0.32 & 0.35 & 0.27 \\
\hline Fs & 2.06 & 1.21 & 2.14 & 1.80 & 3.23 & 1.45 & 5.41 & 2.08 & 1.85 & 2.09 & 2.59 & 2.78 & 2.29 & 1.47 & 1.37 & 1.64 \\
\hline Ol Fo & - & - & - & - & - & - & - & - & - & - & - & - & - & - & - & - \\
\hline $\mathrm{Fa}$ & - & - & - & - & - & - & - & - & - & - & - & - & - & - & - & - \\
\hline Il & 0.23 & 0.17 & 0.13 & 0.21 & 0.44 & 0.23 & 0.99 & 0.46 & 0.55 & 0.40 & 0.42 & 0.46 & 0.51 & 0.04 & 0.34 & 0.40 \\
\hline DI & 76.93 & 82.45 & 78.22 & 79.72 & 75.19 & 85.50 & 77.31 & 81.52 & 81.81 & 81.10 & 77.89 & 78.38 & 81.47 & 79.72 & 82.66 & 83.03 \\
\hline
\end{tabular}

kaline affinities, going from the low-potassium type to the high-potassium type. In this partition, basic lavas, lined along F1, belong to only one series-group B.

The F3 factor (not shown) opposes $\mathrm{MnO}$ to other elements; this phenomenon is attributed to the undetermined content of $\mathrm{MnO}$ in several lavas. The manganese content in acid lavas shows no systematic variation ac- cording to the age and location of the samples; besides, these lavas are free from differentiation as from serial distinctions. The suppression of this element in a new statistical calculation leads to a better score for the first three factors: $89 \%$ variance ( $80 \%$ for F1 and F2) and to the appearance of a new factor $\mathrm{F} 3$ that opposes $\mathrm{K}_{2} \mathrm{O}$ to $\mathrm{Na}_{2} \mathrm{O}$ (that would have been called $\mathrm{F} 4$ in the former 
Table 4. Average and standard deviation of chemical composition of acid-glass shards $(\mathrm{n}=79)$.

\begin{tabular}{lrc}
\hline & Average & $\begin{array}{c}\text { Deviation } \\
\text { Standard }\end{array}$ \\
\hline $\mathrm{SiO}_{2}$ & 72.92 & 2.17 \\
$\mathrm{Al}_{2} \mathrm{O}_{3}$ & 12.81 & 1.05 \\
$\mathrm{FeO}^{*}$ & 1.22 & 0.63 \\
$\mathrm{MnO}$ & 0.05 & 0.06 \\
$\mathrm{MgO}$ & 0.19 & 0.15 \\
$\mathrm{CaO}$ & 0.87 & 0.41 \\
$\mathrm{Na} 2 \mathrm{O}$ & 2.15 & 0.56 \\
$\mathrm{~K}_{2} \mathrm{O}$ & 2.50 & 0.68 \\
$\mathrm{TiO}_{2}$ & 0.17 & 0.13 \\
Total & 92.88 & \\
\hline
\end{tabular}

Note: Total $\mathrm{Fe}$ as $\mathrm{FeO}^{*}$.

statistical calculation). This secondary behavior of $\mathrm{K}_{2} \mathrm{O}$ (independent of the ages and types of lavas) recalls, as that of $\mathrm{MnO}$, an occasional alteration interfering during deposition of pyroclastites.

\section{Chronological Evolution}

Our previous diagrams suggest that groups A (low $\mathrm{K}$ ), B (medium K), and C (high K) belong to different magmatic series. The lava types of the three groups seem to occur successively in time.

During the early Miocene, type A rhyolites appeared. They occurred again in the middle Miocene, associated with type B rhyolites. The end of the early Miocene witnessed the appearance of type $C$ rhyolites.

The late Miocene was a period of very weak volcanic activity. Activity increased during the early Pliocene with less differentiated $\mathrm{A}, \mathrm{B}$, and $\mathrm{C}$ products: rhyo-dacites and dacites.

During the late Pliocene, low-potassic volcanoes emitted their last dacitic lavas. Then, from the late Pliocene to the early Pleistocene, B- and C-group volcanoes emitted progressively more acid lavas. Their activities continued through the late Pleistocene to the Present with rhyolites and a few rhyo-dacites, specifically those belonging to the high-potassic type.

The evolution can be schematized on a time $/ \mathrm{K}_{2} \mathrm{O}$ diagram, if we plot only chemical analyses of $\mathrm{Rh}, \mathrm{Rh}-\mathrm{Dc}$, and $\mathrm{Dc}$, which show a negative $\mathrm{SiO}_{2} / \mathrm{K}_{2} \mathrm{O}$ correlation for each lava type in Figure 6. We concentrate especially on the data from Site 496 ( on Fig. 8) and those from Site $497(\odot, \otimes)$; at these sites evolution of A and C products can be spotted from the early Pliocene to the Present.

\section{Mineral Fragments}

Twenty-eight mineral samples were analyzed: 18 plagioclases, 1 alkaline feldspar, 5 clinopyroxenes, 1 orthopyroxene, and 3 biotites (Tables 2 and 6 ).

\section{Feldspars}

The plagioclases show a large variation of the An content $(18.4 \%-89.7 \%)$, as in all andesitic series. They come from fragments of zoned phenocrysts or microliths; thus they cannot yield any precise information about their parent magma. Though there is no systematic correlation between the An content of plagioclases and the basic composition of the coexisting glass shards, $\mathrm{Ca}$-rich plagioclases coexist with an andesite glass in an upper Pleistocene core from Site 496, and with a dacitic glass in a lower Pliocene core from Site 497 . Only one

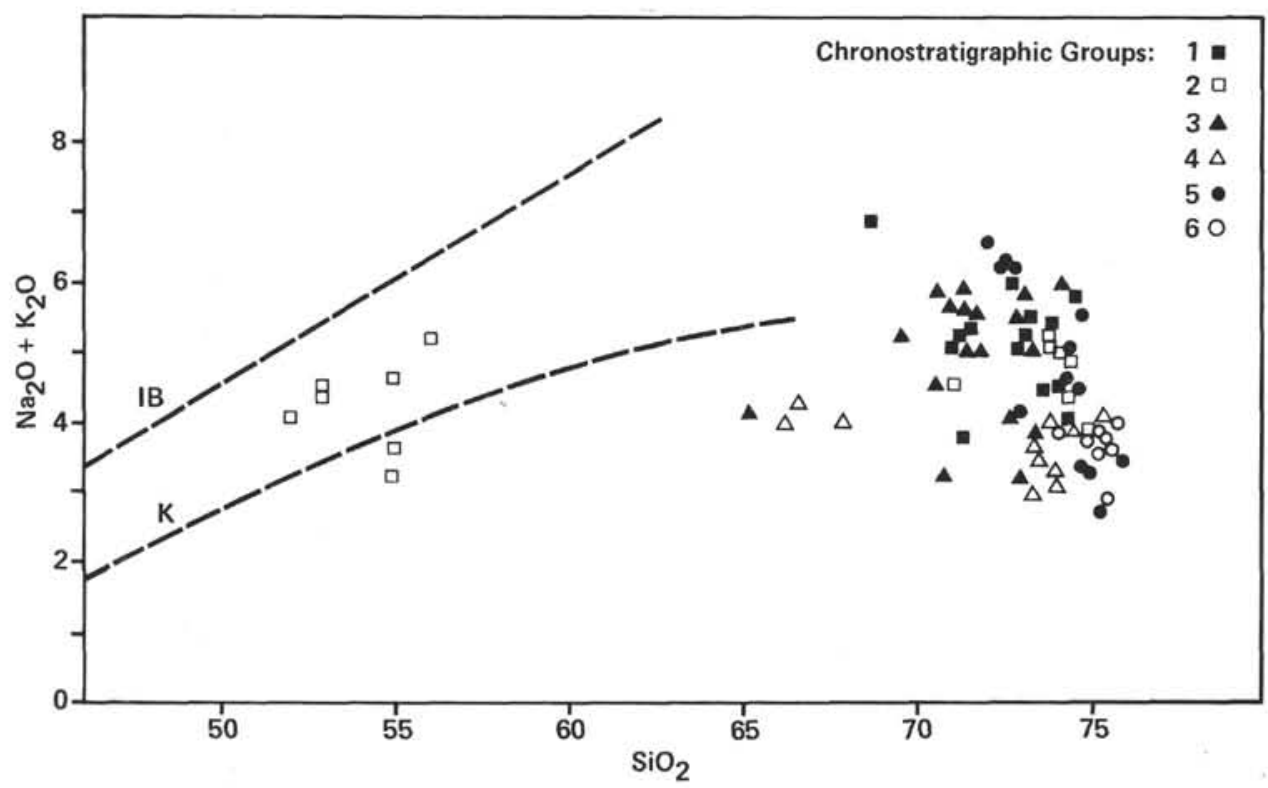

Figure 4. $\mathrm{SiO}_{2} / \mathrm{Na}_{2} \mathrm{O}+\mathrm{K}_{2} \mathrm{O}$ diagram. (Chronostratigraphic groups: $1 \mathbf{E}=$ Present, $2 \square=$ upper Pleistocene, $3 \mathbf{\Delta}=$ Pliocene-Pleistocene boundary, $4 \Delta=$ lower Pliocene, $5 \bullet=$ middle Miocene, and $6 O=$ lower Miocene. IB: boundary of alkaline/subalkaline lavas [Irvine and Baragar, 1971]; K: boundary of alkaline/tholeiitic rocks [Kuno, 1968].) 


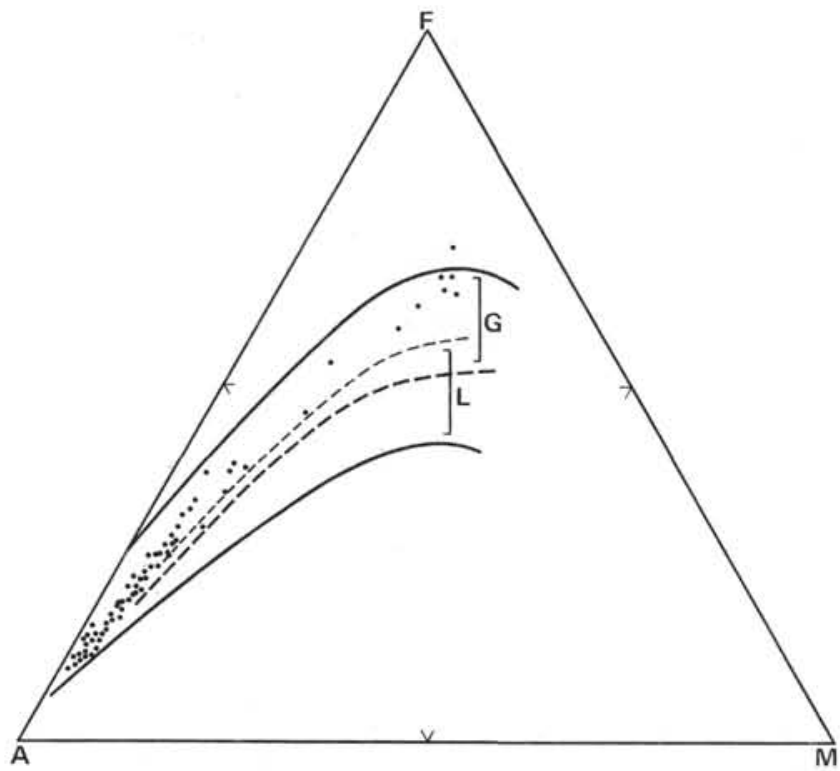

Figure 5. Glass analysis of Leg 67 plotted (small dots) in AFM diagram ( - indicates Central American volcanic rocks [Woodruff et al., 1979]; - - - L indicates ashes and lavas, Santa-Maria, Santiaguito, Fuego, Pacaya, Atitlan, and Izalco [Rose, 1972; Rose et al., 1978; Woodruff et al., 1979; Bardintzeff et al., 1980 and unpublished data]; . . . . . G indicates glassy magmatic inclusions [Bardintzeff et al., 1980]).

alkaline feldspar has been analyzed from Site 495 . Unfortunately, coexisting glass analyses are not available.

\section{Pyroxenes}

Pyroxenes consist of one orthopyroxene (En 70) and five clinopyroxenes of augite composition (En 41-44.5; Fs 16-22; Wo 36-41; see Fig. 9). The orthopyroxene, one clinopyroxene, and three Ca-rich plagioclases are found together with a rhyo-dacitic glass in a lower Pleistocene core from Site 495. Compared with the pyroxene compositions of the Santiaguito dacite (Bardintzeff et al., 1980), the nearest acid volcano, the formation temperature of the cognate clinopyroxene-orthopyroxene (CPX-OPX) (Wood and Banno, 1973), seems to be slightly lower (1174-1181 against $1195-1231^{\circ} \mathrm{C}$ ).

\section{Biotites}

Three analyses of biotites are available from a lower Pliocene core from Site 497; their compositions approach titaniferous phlogopites ( $\left.\mathrm{Fm} 66-67 ; \mathrm{TiO}_{2}: 3.5 \%\right)$. Biotites coexist with clinopyroxenes and $\mathrm{Ca}$-rich plagioclases coming from a dacitic magma. Biotite is common in a calc-alkaline series, even if it is unknown in present dacitic volcanoes of Central America where amphibole is the hydroxilated phase.

\section{COMPARISON WITH ON-LAND DATA}

In Hole 494A (Core 1, Section 1) we found a dacitic glass similar to that from Santiaguito, and in Hole 496 (Core 3, Section 4), a rhyolitic glass showing a composition close to "Los Chocoyos" tephras from Atitlan Lake (Drexler et al., 1980). Apart from these cases, Leg 67 "glass shards" are systematically poorer in $\mathrm{Al}_{2} \mathrm{O}_{3}$ and $\mathrm{Na}_{2} \mathrm{O}$ than the latest lavas from Central America (Rose, 1972; Rose et al., 1978), which gives them a lighter calc-alkaline tendency. Similar compositions, however, are known in some ancient lavas (Woodruff et al., 1979). The discrepancy may arise from either analytic technique or alteration during deposition (loss of $\mathrm{NaO}_{2}$ ), however, it may represent real fluctuations in magma composition.

Our data are scarce concerning Miocene to Pliocene terrestrial lavas contemporaneous with submarine ashes.

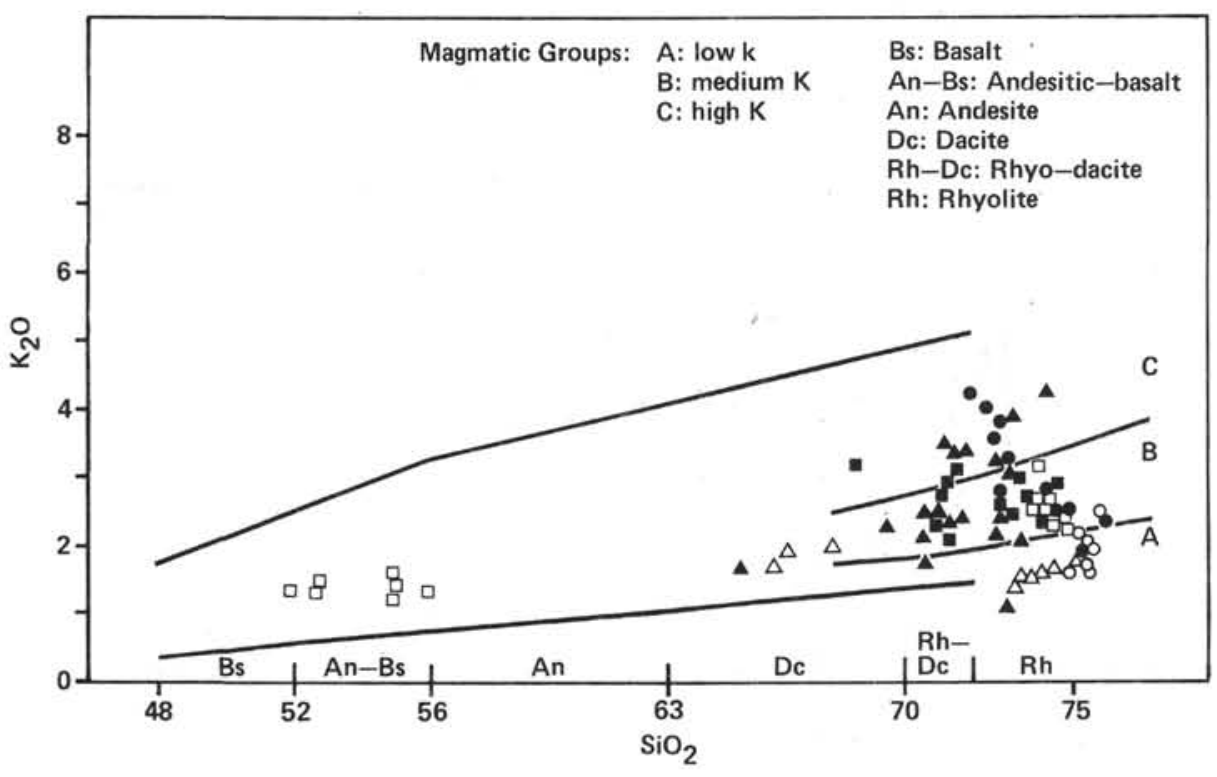

Figure 6. $\mathrm{SiO}_{2} / \mathrm{K}_{2} \mathrm{O}$ diagram. (For an explanation of symbols denoting chronostratigraphic groups, see Fig. 4. Magmatic groups: $\mathrm{A}=$ low $\mathrm{K} ; \mathrm{B}=$ medium $\mathrm{K} ; \mathrm{C}=$ high $\mathrm{K}-$ these are the typological boundaries defined by Pecerillo and Taylor [1976].) 
Table 5. Variance of the factors F1, F2, and F3, and correlation coefficients.

\begin{tabular}{|c|c|c|c|c|c|c|c|c|c|c|c|}
\hline \multicolumn{4}{|c|}{$\mathrm{F} 1(52.22 \%)$} & \multicolumn{4}{|c|}{ F2 (18.78\%) } & \multicolumn{4}{|c|}{ F3 $\left(11.33 \%_{0}\right)$} \\
\hline \multicolumn{2}{|c|}{$(+)$} & \multicolumn{2}{|c|}{$(-)$} & \multicolumn{2}{|c|}{$(+)$} & \multicolumn{2}{|c|}{$(-)$} & \multicolumn{2}{|c|}{$(+)$} & \multicolumn{2}{|c|}{$(-)$} \\
\hline $\mathrm{FeO}$ & $(0.94)$ & & & & & $\overline{\mathrm{CaO}}$ & $(0.39)$ & & & $\overline{\mathrm{TiO}_{2}}$ & $(0.15)$ \\
\hline $\mathrm{MgO}$ & (0.94) & & & $\mathrm{K}_{2} \mathrm{O}$ & $(0.77)$ & $\mathrm{SiO}_{2}$ & $(0.30)$ & & & $\mathrm{CaO}$ & $(0.10)$ \\
\hline $\mathrm{TiO}_{2}$ & $(0.85)$ & $\mathrm{SiO}_{2}$ & $(0.89)$ & $\mathrm{Na}_{2} \mathrm{O}$ & $(0.72)$ & $\mathrm{MgO}^{\circ}$ & $(0.20)$ & $\mathrm{MnO}$ & $(0.98)$ & $\mathrm{SiO}_{2}$ & $(0.06)$ \\
\hline $\mathrm{CaO}$ & $(0.84)$ & $\mathrm{K}_{2} \mathrm{O}$ & $(0.15)$ & $\mathrm{Al}_{2} \mathrm{O}_{3}$ & $(0.51)$ & $\mathrm{TiO}_{2}$ & $(0.15)$ & $\mathrm{Al}_{2} \mathrm{O}_{3}$ & $(0.14)$ & $\mathrm{Na}_{2} \mathrm{O}$ & $(0.06)$ \\
\hline $\mathrm{Al}_{2} \mathrm{O}_{3}$ & $(0.76)$ & & & & & $\mathrm{FeO}$ & $(0.12)$ & & & $\mathrm{FeO}$ & $(0.02)$ \\
\hline $\mathrm{Na}_{2} \mathrm{O}$ & $\{0.30\}$ & & & & & $\mathrm{MnO}$ & $(0.10)$ & & & $\mathrm{K}_{2} \mathrm{O}$ & $(0.01)$ \\
\hline $\mathrm{MnO}$ & $(0.10)$ & & & & & & & & & $\mathrm{MgO}$ & $(0.00)$ \\
\hline
\end{tabular}

Note: $(+)$ and $(-)$ indicate positive or negative correlation.

These lavas might be less calc-alkaline than more recent lavas.

\section{DISTRIBUTION OF ASH LAYERS AND NEOGENE TO QUATERNARY EXPLOSIVE VOLCANISM RECORD}

\section{METHOD}

We assume that the record of explosive volcanic activity on land can be read, with certain limitations, in the distribution of ash layers in
DSDP cores. Many other studies interpret the occurrence of ash in DSDP cores in the same way (see a partial review in Cadet and Fujioka, 1980).

To investigate the history of explosive volcanism in Middle America we took into account all the ash layers, even the minor ones, as well as ash pods. After checking whenever possible with the smear slides and finding that the glass content was about $60 \%$ and the amount of reworked material low, we assumed that such intervals are related to a single ash layer. Then we would plot the number of ash layers versus time by dividing the sediment section into intervals of $1 \mathrm{~m}$.y., using sedimentation accumulation curves and fossil zone boundaries; we would then estimate the number of ash layers in this interval and adjust for the degree of core recovery (cf., Hein et al., 1978; Cadet and Fujioka, 1980).

\section{Limitations}

Although this relatively simple method of recording explosive volcanism can provide results complementary to those obtained on land (where erosion destroys numerous witnesses), it is limited by three main factors:

1) The only records of explosive silicic volcanism are those carried to the site by the prevailing winds, whose directions can vary with time.

2) Sedimentary environment plays an important role; aspects such as sedimentation rate, slumping erosion on the slope, bioturbation, etc.,

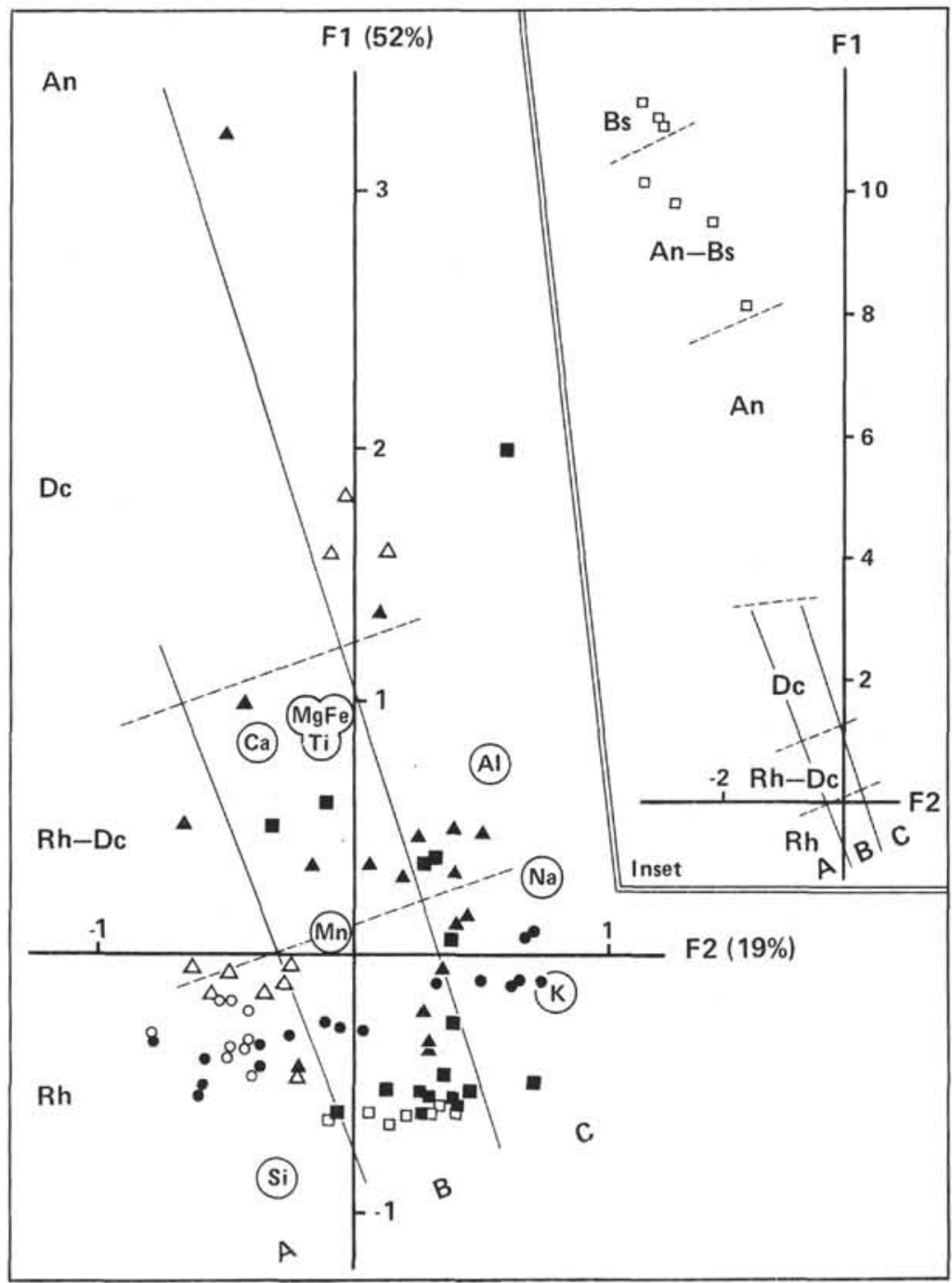

Figure 7. $F_{1} / F_{2}$ diagram, principal component analysis. (Bs = basa:ts; $A n-B s=a n-$ desitic-basalt; $\mathrm{An}=$ andesite $\mathrm{Dc}=$ dacite $\mathrm{Rh}-\mathrm{Dc}=$ rhyo-dacite; $\mathrm{Rh}=$ rhyolite. The solid lines indicate the typological boundaries, defined in Fig. 6 caption; see Fig. 4 for identification of chronostratigraphic groups.). 


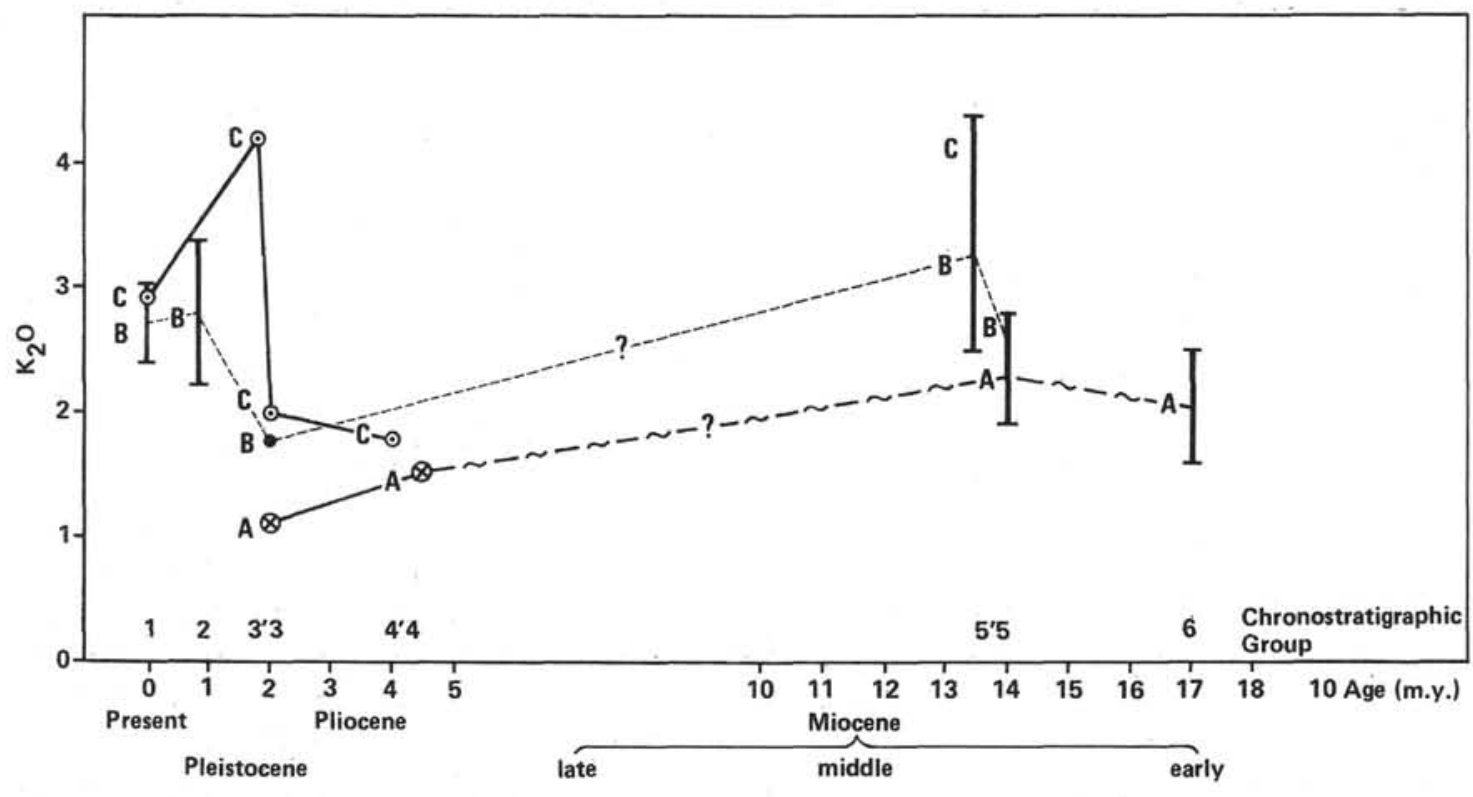

Figure 8. Time $/ \mathrm{K}_{2} \mathrm{O}$ diagram. $(\bullet=$ Site $496, \otimes$ and $\odot=$ Site 497 . See Fig. 6 for an explanation of A-C, Fig. 4 for identification of chronostratigraphic groups.)

Table 6. Microprobe arialysis of minerals.

\begin{tabular}{|c|c|c|c|c|c|c|c|c|c|}
\hline \multirow{3}{*}{$\begin{array}{l}\text { Hole } \\
\text { Core-Section } \\
\text { Analysis No. }\end{array}$} & \multicolumn{4}{|c|}{496} & \multirow[b]{2}{*}{$2-5$} & \multicolumn{4}{|r|}{497} \\
\hline & \multirow{2}{*}{$\frac{5-2}{\mathrm{Pl} 67}$} & \multicolumn{2}{|l|}{$7-1$} & \multirow{2}{*}{$\frac{30-5}{\mathrm{Pl} 74}$} & & \multicolumn{3}{|c|}{$17-3$} & \multirow{2}{*}{$\frac{19 .}{\mathrm{Pl} 3}$} \\
\hline & & Pl $18 \quad$ P & P1 26 & & PI 29 & Pl 3 & Pl 6 & PI 8 & \\
\hline $\mathrm{SiO}_{2}$ & 64.10 & $52.36 \quad 5$ & 53.99 & 54.7 & 61.57 & 56.82 & 46.72 & 51.05 & 59.41 \\
\hline $\mathrm{TiO}_{2}$ & - & 0.28 & 0.21 & 0.0 & - & - & - & - & 0.08 \\
\hline $\mathrm{Al}_{2} \mathrm{O}_{3}$ & 22.37 & $25.45 \quad 2$ & 25.16 & 28.5 & 24.36 & 26.37 & 32.80 & 29.48 & 25.75 \\
\hline $\mathrm{FeO}{ }^{*}$ & 0.19 & 3.71 & 2.94 & 0.5 & 0.09 & 0.19 & 0.66 & 1.35 & 0.16 \\
\hline $\mathrm{CaO}$ & 3.84 & $12.11 \quad 1$ & 10.64 & 11.3 & 6.00 & 8.85 & 16.71 & 14.47 & 7.41 \\
\hline $\mathrm{Na}_{2} \mathrm{O}$ & 8.87 & 3.73 & 4.68 & 4.7 & 7.70 & 6.15 & 1.79 & 3.33 & 6.60 \\
\hline $\mathrm{K}_{2} \mathrm{O}$ & 0.80 & 0.43 & 0.46 & 0.2 & 1.00 & 0.33 & 0.11 & 0.09 & 0.54 \\
\hline Total & 100.18 & $\begin{array}{ll}99.33 & 9\end{array}$ & 98.67100 . & 100.1 & 100.72 & 98.71 & 98.79 & 99.77 & 99.96 \\
\hline $\mathrm{Si}$ & 2.831 & a & 2. & 110 & 2.72 & 2.581 & 2.175 & 2.340 & 2.65 \\
\hline $\mathrm{Ti}$ & - & & - & 0.0 & - & - & - & - & 0.00 \\
\hline Al & 1.165 & & & 876 & 1.27 & 1.412 & 1.800 & 1.593 & 1.35 \\
\hline $\mathrm{Fe}$ & 0.007 & & & .026 & 0.00 & 0.007 & 0.026 & 0.052 & 0.00 \\
\hline $\mathrm{Ca}$ & 0.182 & & & .883 & 0.28 & 0.431 & 0.834 & 0.711 & 0.35 \\
\hline $\mathrm{Na}$ & 0.760 & & & .098 & 0.66 & 0.542 & 0.161 & 0.296 & 0.57 \\
\hline K & 0.045 & & & .004 & 0.05 & 0.019 & 0.007 & 0.005 & 0.03 \\
\hline Total & 4.990 & & & 997 & 4.95 & 4.992 & 5.003 & 4.997 & 4.97 \\
\hline Or & 4.57 & & & i.7 & 5.6 & 1.96 & 0.66 & 0.51 & 3.22 \\
\hline$A b$ & 77.01 & & & 42.5 & 65.9 & 54.62 & 16.11 & 29.24 & $\begin{array}{l}59.73 \\
37.05\end{array}$ \\
\hline An & 18.42 & & 89. & 55.7 & 28.4 & 43.42 & 83.23 & 70.25 & 37.05 \\
\hline Hole & \multicolumn{2}{|c|}{496} & 497 & $494 \mathrm{~A}$ & \multicolumn{2}{|c|}{495} & \multicolumn{3}{|c|}{497} \\
\hline \multirow{2}{*}{$\begin{array}{l}\text { Core-Section } \\
\text { Analysis No. }\end{array}$} & $7-1$ & $19-4$ & $36-7$ & $17-2$ & $5-$ & & & $36-7$ & \\
\hline & CPX 24 & CPX 33 & CPX 27 & CPX 22 & CPX 15 & OPX 13 & Bi 28 & Bi 29 & Bi 31 \\
\hline $\mathrm{SiO}_{2}$ & 50.58 & 52.47 & 50.30 & 52.28 & 51.74 & 53.63 & 37.97 & 37.14 & 36.91 \\
\hline $\mathrm{TiO}_{2}$ & 0.47 & 0.70 & 0.68 & 0.41 & 0.55 & 0.20 & 3.35 & 3.76 & 3.69 \\
\hline $\mathrm{Al}_{2} \mathrm{O}_{3}$ & 3.19 & 1.46 & 4.05 & 3.24 & 1.49 & 1.28 & 14.38 & 14.63 & 14.63 \\
\hline $\mathrm{FeO}^{*}$ & 10.16 & 11.97 & 9.68 & 11.05 & 13.38 & 16.80 & 14.16 & 13.32 & 14.14 \\
\hline $\mathrm{MnO}$ & 0.17 & 0.49 & 0.41 & 0.42 & 0.24 & 0.61 & 0.02 & 0.18 & 0.15 \\
\hline $\mathrm{MgO}$ & 15.61 & 14.70 & 14.99 & 14.06 & 14.47 & 25.12 & 15.92 & 15.40 & 15.60 \\
\hline $\mathrm{CaO}$ & 19.03 & 17.39 & 20.09 & 18.61 & 17.39 & 1.74 & - & - & - \\
\hline $\mathrm{Na}_{2} \mathrm{O}$ & 0.25 & 0.39 & 0.38 & 0.24 & 0.31 & 0.01 & 0.79 & 0.63 & 0.65 \\
\hline $\mathrm{K}_{2} \mathrm{O}$ & - & - & - & - & 0.02 & 0.02 & 8.74 & 8.91 & 8.61 \\
\hline $\mathrm{H}_{2} \mathrm{O}$ & - & - & - & - & - & - & 4.04 & 3.99 & 3.99 \\
\hline Total & 99.47 & 99.62 & 100.57 & 100.30 & 99.59 & 99.41 & 99.38 & 97.99 & 98.37 \\
\hline Si & 1.896 & i. 968 & 1.869 & 1.941 & 1.954 & 1065 & 5.6 & 5.582 & 5.540 \\
\hline T & 0.013 & 0.020 & 0.0 & 0.011 & 0.016 & 0.006 & 0.374 & 0.425 & 0.416 \\
\hline Al & 0.141 & 0.064 & 0.177 & 0.142 & 0.066 & 0.056 & 2.513 & 2.592 & 2.588 \\
\hline $\mathrm{Fe}$ & 0.319 & 0.375 & 0.301 & 0.343 & 0.423 & 0.515 & 1.756 & 1.674 & 1.775 \\
\hline $\mathrm{Mn}$ & & 0.016 & 0.013 & 0.013 & 0.008 & 0.019 & 0.003 & 0.023 & 0.019 \\
\hline $\mathrm{Mg}$ & 0.872 & 0.822 & 0.830 & 0.778 & 0.815 & 1.372 & 3.520 & 3.449 & 3.491 \\
\hline C & & 0.699 & 0.800 & 0.740 & 0.704 & 0.068 & - & - & - \\
\hline $\mathrm{Na}$ & 0.018 & 0.029 & 0.027 & 0.017 & 0.023 & 0.001 & 0.228 & 0.183 & 0.189 \\
\hline K & - & - & - & - & 0.001 & 0.001 & 1.654 & 1.709 & 1.648 \\
\hline $\mathrm{OH}$ & - & - & - & - & - & - & 2.000 & 2.000 & 2.000 \\
\hline Total & 4.028 & 3.993 & 4.036 & 3.985 & 4.010 & 4.003 & 17.679 & 17.637 & 17.666 \\
\hline Wo & 38.9 & 36.56 & & 39.49 & 36.12 & 3.46 & & & \\
\hline En & & 42.98 & & & & 69.50 & & & \\
\hline Fs & 16.52 & 20.46 & 16.13 & 19.01 & 22.08 & 27.04 & & & \\
\hline
\end{tabular}

Note: Plagioclases (Pl), alkaline feldspar (F), clinopyroxenes (CPX), orthopyroxenes (OPX), and biotites (Bi). Total $\mathrm{Fe}$ as $\mathrm{FeO},-=$ no data available.

Fe contamination. 


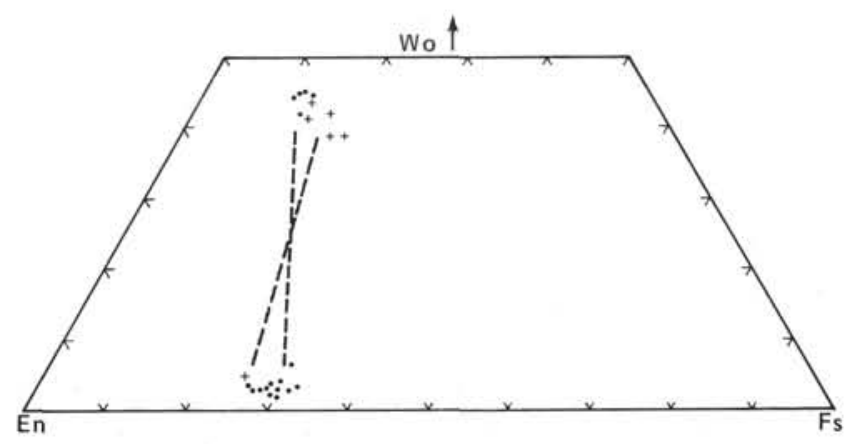

Figure 9. Wo-En-Fs diagram of pyroxenes (+ indicates Leg 67; • indicates Santiaguito [Bardintzeff et al., 1980 and unpublished data], ---- indicates coexisting CPX-OPX).

are expected to be variable. Disseminated glass could give a better picture of explosive volcanism than ash layers, owing to the problem of bioturbations and bad core recovery in the latter. Arthur et al. (1980) have shown that the pattern of concentration of disseminated glass in the Japan Trench transect (Leg 57) is roughly similar to the pattern of ash-layer frequency but it greatly depends on influxes of clastic detritus and on the depositional environment, in particular, for slope sites. Besides, the method seems very dependent on the amount and quality of information (number of smear slides, assumption that smear-slide estimates of volcanic glass are accurate, etc.). We will discuss this point with respect to the Leg 67 data and will use the information provided by disseminated glass compared to data provided by ash layers.

3) Lastly, alteration and diagenesis are also important considerations. Hein and Scholl (1978) stress the fact that diagenesis reduces the number of ash layers; they note that ash beds in which smectitic clay minerals and zeolites have been transformed are subsequently difficult to recognize by visual inspection. We lack data on this subject, but alteration and diagenesis probably are significant only in older levels, specifically in the middle lower Miocene carbonate ooze drilled at Site 495 , which contains thin ash.

\section{Patterns of Explosive Volcanic Activity}

\section{Trench Slope Sites}

Plots of the number of ash layers versus time in continental slope Sites 496, 497, 494, and 498 show a sporadic and poorly documented period of activity around 14 to $16 \mathrm{Ma}$ (early Miocene), no activity in the late Miocene, and a sharp rise from the early Pliocene, with a peak during the Quaternary (Fig. 10, A and B). Closer inspection of curves shows: (1) At Site 496, the nearest to the continent, there has been a large increase in the number of ash layers during the last million years, but the Pliocene layer is too thin for a reliable analysis of volcanism intensity. (2) Site 497 completes Site 496 data and confirms that the Pliocene to Quaternary period of explosive volcanicity had a slow start during the early Pliocene and a fast increase from the late Pliocene onward. Because of its greater distance from the volcanoes, the number of Quaternary ash layers at Site 497 is less important than at Site 496. (3) The ash record at Site 494 is similar to that at Sites 496 and 497 , but at Site 498 the recovery is too scarce for useful results.

\section{Trench Floor Sites}

Site 499 also documents a similar increase in volcanicity from the late Pliocene onward. A lack of samples from the early Pliocene makes is impossible to identify the beginning of this period. Quaternary trench-fill turbidites hide some of the recent activity.
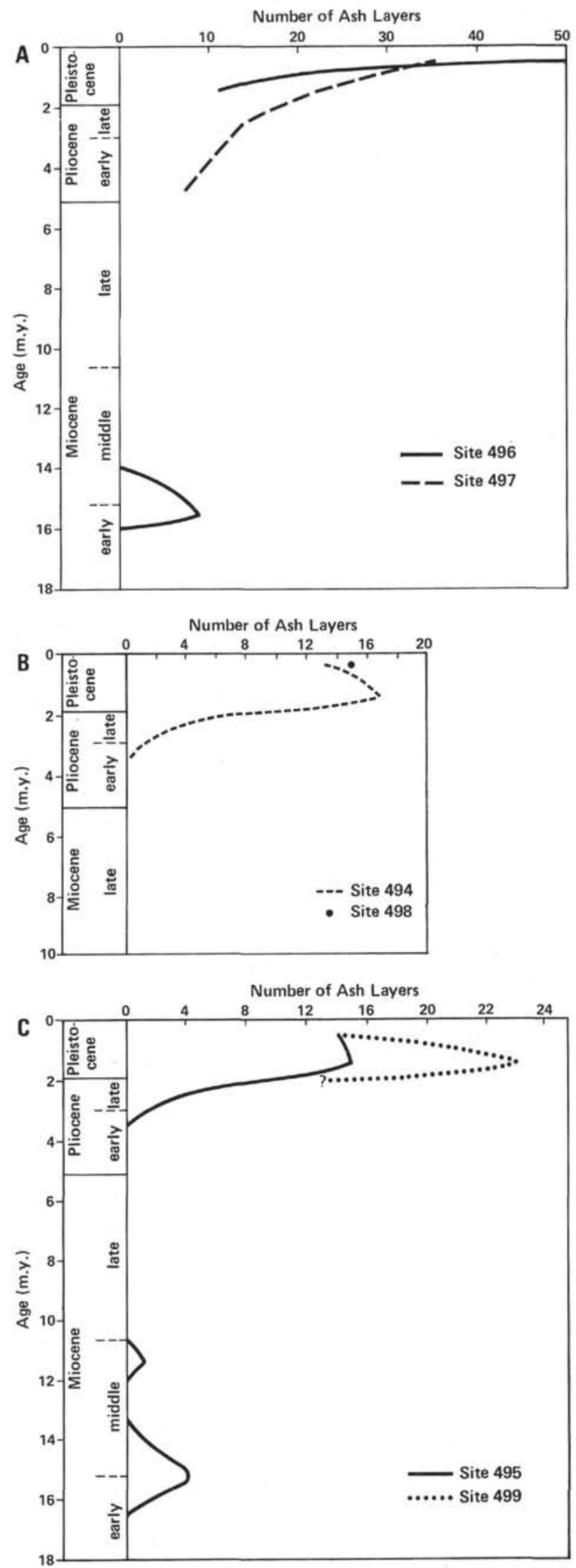

Figure 10. A-C. Periods of explosive volcanism in the Middle America Trench transect off Guatemala (Leg 67) as recorded by ash beds (data are plotted at a uniform interval of 1 m.y. and with correction for core recovery). 
Drilling at Site 500 penetrated Quaternary siliceous biogenic mud and turbidites devoid of ash layers and thus does not convey any information on the matter.

\section{Oceanic Reference Site}

Site 495 (Fig. 10C) shows a moderate rise in volcanic activity between 16 and $14 \mathrm{Ma}$, then an absence after sporadic activity around 12 to $11 \mathrm{Ma}$. About $4 \mathrm{Ma}$, the activity resumes sharply, reaching a maximum between 2 and $1 \mathrm{Ma}$.

In short, Leg 67 curves display two stages of high volcanic activity, an early one around $15 \mathrm{Ma}$ and a late, more intensely active one starting around $4 \mathrm{Ma}$ (Fig. 10, A-C). We must stress that these results represent only the record of explosive silicic volcanism carried to the site by the prevailing winds.

The sharp increase of explosive volcanism during the Quaternary, noticeable only at Sites 496 and 497, seems to result from an increase in the frequency of eruptions rather than from an increase in their intensity.

\section{Comparison with Disseminated Glass}

As shown by Arthur et al. (1980), ideally, disseminated glass should give an even better picture of explosive volcanism than ash layers, owing to the problems of bioturbation and nonrecovery of the latter.

Figure 11 shows the percentage of volcanic glass in smear slide; a few general trends appear, such as the abundance of glass during the Quaternary at Sites 496 and 497, but the presence of glass at almost all levels emphasizes the importance in a trench-slope environment of redistribution and redeposition of volcanic detritus or direct transport from land areas.

\section{COMPARISON AND DISCUSSION}

The Leg 66 Middle America Trench transect off Mexico displays two periods of high volcanic activity, an early one at about 18 to $15 \mathrm{Ma}$ and a late one during the Quaternary, with two less important episodes in the late Miocene and in the Pliocene. Middle Miocene activity as represented in Leg 66 sites is unknown due to sedimentary hiatus. Common to both Leg 66 and Leg 67 sites are an episode 17- to 14-Ma, with a maximum around $16 \mathrm{Ma}$ (Leg 66) or around $15 \mathrm{Ma}(\mathrm{Leg} \mathrm{67)}$. There is a weak recurrence of volcanism during the late Miocene, 8 to $10 \mathrm{Ma}$ in Leg 66 and $11 \mathrm{Ma}$ in Leg 67. On the contrary, the Pliocene to Quaternary tells a somewhat different story. In Leg 66 sites from $7 \mathrm{Ma}$, activity resumes moderately during the Pliocene, with a peak between 4 and $2 \mathrm{Ma}$, decreases between 2 and $1 \mathrm{Ma}$, and shows a steep increase during the last million years. In Leg 67 sites there is a rough increase starting more or less early in the early Pliocene and developing in the Quaternary. Because the continental sites of Leg 67 are close to volcanic sources, we can infer that these differences are probably due to local rather than global causes-the Pliocene to Quaternary history deduced from Leg 67 data corresponding to the northern part of the Pacific volcanic chain.

The history of explosive volcanism off Middle America drawn from Legs 66 and 67 fits and completes the synthesis of Kennett et al. (1977), which outlines, in order of apparent decreasing importance, three episodes: Quaternary; early to middle Pliocene (5-3 Ma); and late Miocene (10-9 Ma). We also record the middle Miocene episodes, the "Columbian" of Kennett et al. (1977), which seems to be centered at about 15 to $14 \mathrm{Ma}$, and is well established in the Tertiary sequences of Honduras (Williams and McBirney, 1969) and Nicaragua (McBirney and Williams, 1965).

\section{CONCLUSION}

The ash-layers deposited off Guatemala in this eastern Pacific subduction zone are related to three magmatic groups differentiated by their relative content in aluminas and alkaline elements (calc-alkaline character).

A first weakly calc-alkaline, potassic, differentiated magma emerged during the early and middle Miocene. Its last rhyodacitic occurrences were in the late Miocene. The moderately potassic magma emerged in the middle Miocene, with rhyolites. Rhyo-dacites appeared in the Pliocene to Pleistocene, then either basaltic andesites or rhyolites in the late Pleistocene. This moderately potassic magma is responsible for the bulk of the Quaternary ash deposits, which are essentially rhyolitic. Its magmatic bimodality corresponds to the products from diverse volcanoes now found at Fuego and Pacaya, Atitlan and Izalco (basic lavas), and Santa Maria and Santiaguito (acid lavas). The highly calc-alkaline and potassic magma was marked by rhyolites towards the end of the middle Miocene. It showed again in the early Pliocene with dacites turning to rhyo-dacites, then rhyolites in the late Pliocene and early Pleistocene. At present it supplies a few rhyolitic products.

The fact must be stressed that such a schema only concerns the products of explosive volcanism encased in marine sediments in the form of glassy shards a hundred kilometers offshore. Besides, sampling is limited and only partially represents the real activity of the volcanoes. The results of this partial study, however, show the importance of systematically developing sampling and analysis of ash layers in deep-sea cores.

Considering all the data on ash layers gathered on Legs 66 and 67, a coherent history of the explosive volcanism off Central America can be drawn. This history includes well-marked episodes during the middle Miocene (16-15 Ma) and early late Miocene (11-9 Ma), and resumption of activity from the Pliocene leading to a marked increase in the Quaternary (cf., Kennett and Thunell, 1975).

\section{ACKNOWLEDGMENTS}

We would like to acknowledge the Leg 67 scientific staff for providing the samples, the BRGM-CNRS Camebax microprobe analyzer team and M. Tallet for their help, R. P. Menot, R. Brousse, R. Maury, D. Velde, and W. Coulbourn for useful comments, and J. Martinez for typing. This research was supported by a CNRS grant (ATPIPOD).

\section{REFERENCES}

Arthur, M. A., von Huene, R., and Adelseck, C. G., 1980. Sedimentary evolution of the Japan Fore-arc region off northern Honshu, Legs 56 and 57, Deep Sea Drilling Project. In Scientific Party, Init. 


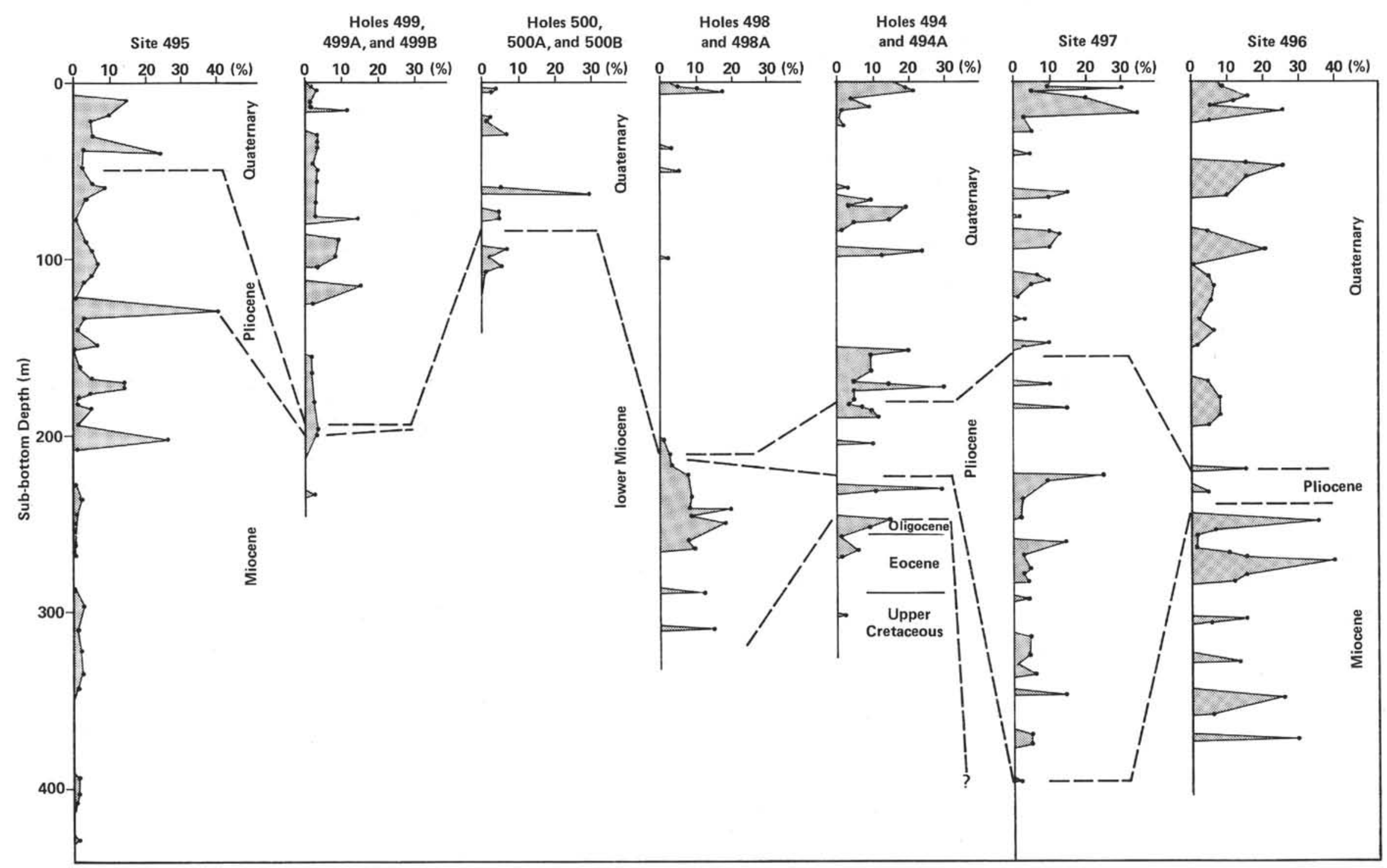

Figure 11. Percentage of volcanic glass in smear slides at all Leg 67 DSDP sites. 
Repts. DSDP, 56, 57, Pt. 1: Washington (U.S. Govt. Printing Office), 521-568.

Aubouin, J., von Huene, R., and Leg 67 Scientific staff, 1979. Premiers résultats des forages profonds dans le Pacifique au niveau de la fosse du Guatemala (fosse d'Amérique Centrale) (Leg 67 du Deep Sea Drilling Project. Mai-juin 1979). C.R. Acad. Sci. Ser. $D, 289: 1215-1220$.

Bardintzeff, J. M., Brousse, R., Clocchiatti, R., and Weiss, J., 1980. Evolution des phenocristaux et de leurs inclusions magmatiques dans la "dacite" du dome du Santiaguito (Guatemala). C.R. Acad. Sci. Ser. D, 290:743-746.

Cadet, J. P., and Fujioka, K., 1980. Neogene volcanic ashes and explosive volcanism: Japan Trench transect, Leg 57, Deep Sea Drilling Project. In Scientific Party, Init. Repts. DSDP, 56, 57, Pt. 2: Washington (U.S. Govt. Printing Office), 1027-1041.

Cadet, J. P., Thisse, Y., Pouclet, A., Bardintzeff, J. M., and Stephan, J. F., in press. Tephra from Deep Sea Drilling Project Leg 66: Middle America Trench transect (southern Mexico). In Watkins, J. S., Moore, J. C., et al., Init. Repts. DSDP, 66: Washington (U.S. Govt. Printing Office).

Carr, M. J., Rose, W. I., and Mayfield, D. G., 1979. Potassium content of lavas and depth to the seismic zone in Central America. $J$. Volcanol. Geotherm. Res., 5(3/4):387-401.

Drexler, J. W., Rose, W. I., Sparks, R. S. J., and Ledbetter, M. T., 1980. The Los Chocoyos ash, Guatemala: a major stratigraphic marker in Middle America and in three ocean basins. Quat. Res., $13: 327-345$.

Eggers, A. A., and Chavez, D., 1979. Temporal gravity variations at Pacaya volcano, Guatemala. J. Volcanol. Geotherm. Res., 6(3/4): 391-402.

Fujioka, K., Furuta, T., and Arai, F., 1980. Petrography and geochemistry of volcanic glass: Leg 57. Deep Sea Drilling Project. In Scientific Party, Init. Repts. DSDP, 56, 57, Pt. 2: Washington (U.S. Govt. Printing Office), 1049-1066.

Hein, J. R., and Scholl, D. W., 1978. Diagenesis and distribution of late Cenozoic volcanic sediment in the southern Bering sea. Geol. Soc. Am. Bull., 89:197-210.

Hein, J. R., Scholl, D. W., and Miller, J., 1978. Episodes of Aleutian Ridge explosive volcanism. Science, 199:137-141.

Irvine, T. N., and Baragar, W. R. A., 1971. A guide to the chemical classification of the common volcanic rocks. Can. J. Earth Sci., $8: 523-548$.
Kennett, J. P., McBirney, A. R., and Thunell, R. C., 1977. Episodes of Cenozoic volcanism in the circum-Pacific region. J. Volcanol. Geotherm. Res., 2:145-163.

Kennett, J. P., and Thunell, R. C., 1975. Global increase in Quaternary explosive volcanism. Science, 187:497-503.

Kuno, H., 1968. Differentiation of basalt magmas. In Hess, H. H., and Poldervaart, A. (Eds.), Basalts (Vol. 2): New York (Interscience, Wiley), 623-688.

Lebart, L., Morineau, A., and Fenelon, J. P., 1979. Traitement des Données Statistiques: Paris (Dunod Ed.).

McBirney, A. R., and Williams, H., 1965. Volcanic history of Nicaragua. Univ. Calif. Berkeley Publ. Geol. Sci., 55:1-65.

Pecerillo, A., and Taylor, S. R., 1976. Geochemistry of Eocene calcalkaline volcanic rocks from the Kastamou area, northern Turkey. Contrib. Mineral. Petrol., 58:63-81.

Rose, W. I., 1972. Santiaguito volcanic dome, Guatemala. Geol. Soc. Am. Bull., 83:1413-1434.

Rose, W. I., Anderson, A. T., Woodruff, L. G., and Bonis, S. B., 1978. The October 1974 basaltic tephra from Fuego volcano: description and history of the magma body. J. Volcanol. Geotherm. Res., 4:3-53.

Scheidegger, K. F., Jezek, P. A., and Ninkovich, D., 1978. Chemical and optical studies of glass shards in Pleistocene and Pliocene ash layers from DSDP Site 192, northwest Pacific ocean. J. Volcanol. Geotherm. Res., 4:99-116.

Thornton, C. P., and Tuttle, O. F., 1960. Chemistry of igneous rocks. I, differentiation index. Am. J. Sci., 258:664-684.

von Huene, R., Aubouin, J., and Leg 67 Scientific Staff, 1980. Leg 67: the Deep Sea Drilling Project Mid-America Trench transect off Guatemala. Geol. Soc. Am. Bull., 91, Pt. 1:421-432.

Williams, H., and McBirney, A. R., 1969. Volcanic history of Honduras. Univ. Calif. Berkeley Publ. Geol. Sci., 85:1-101.

Wood, B. J., and Banno, S., 1973. Garnet-orthopyroxene and orthopyroxene-clinopyroxene relationships in simple and complex systems. Contrib. Mineral. Petrol., 42:109-124.

Woodruff, L. G., Rose, W. I., and Rigot, W., 1979. Contrasting fractionation patterns for sequential magmas from two calc-alkaline volcanoes in Central America. J. Volcanol. Geotherm. Res., $4: 217-240$. 

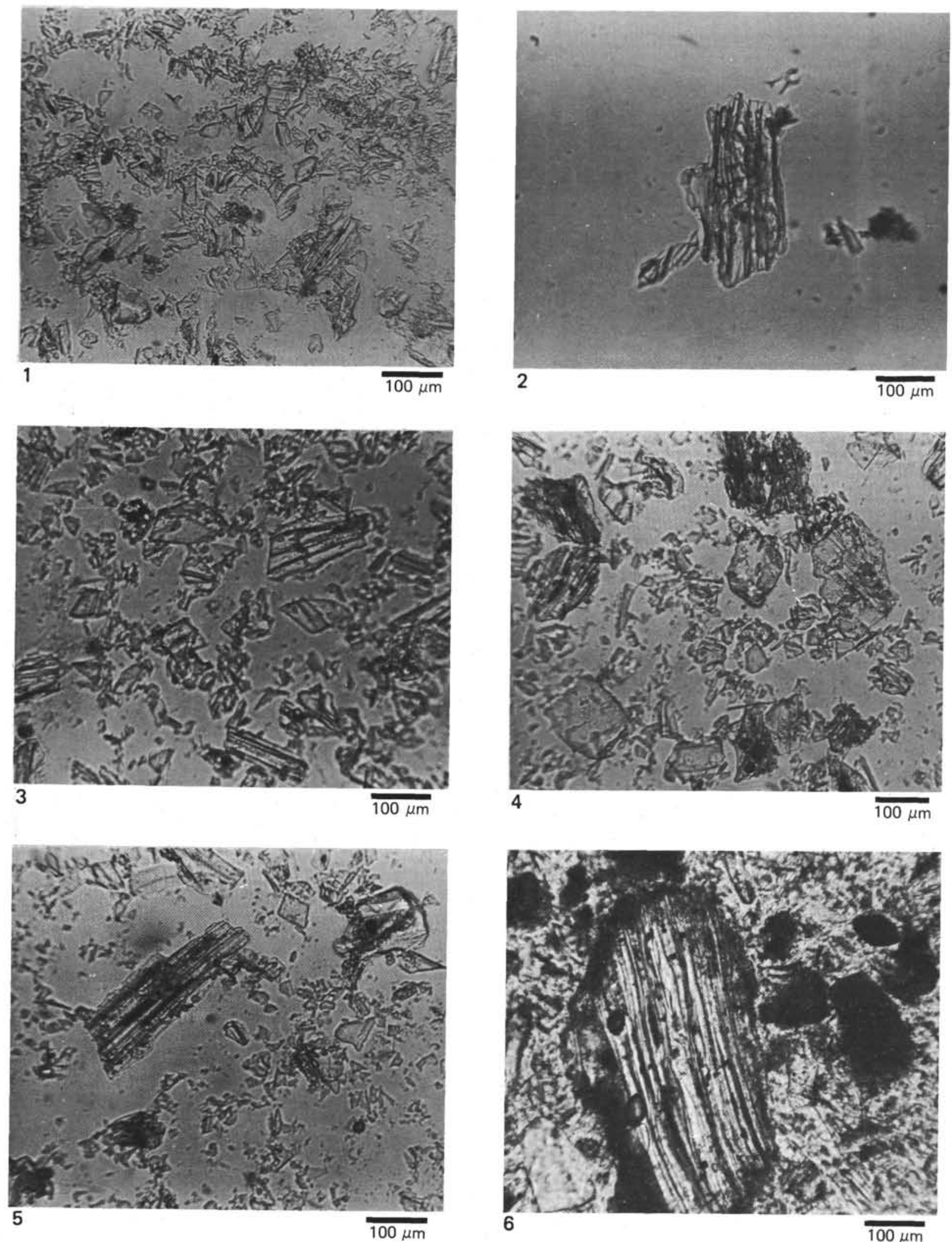

Plate 1. Smear slides of volcanic ashes. 1. Mixture of volcanic glass shards (flattened and tubular fragments). $\times 125$. Sample 497-42-7, 45 cm. Lower Pliocene. 2. A typical elongate tubular pumice fragment. $(\times 125)$. Sample $497-36-7,3 \mathrm{~cm}$. Lower Pliocene. 3. Clear angular and smooth glass shards with some large tubular vesicle fragments. $\times 125$. Sample $497-42-7,45 \mathrm{~cm}$. Lower Pliocene. 4. Clear shards, micropumices, and some opaque minerals. $\times 125$. Sample 496-5-2, $48 \mathrm{~cm}$. Quaternary. 5. A lot of little clear shards and a huge tubular glass with clays and oxides. $\times 125$. Sample $496-5-2,48 \mathrm{~cm}$. Quaternary. 6 . Thin section of volcanic ashes-a relatively important glass tubular vesicle and some brown clay. $\times 125$. Sample $494 \mathrm{~A}-17-2,118 \mathrm{~cm}$. Upper Pliocene. 


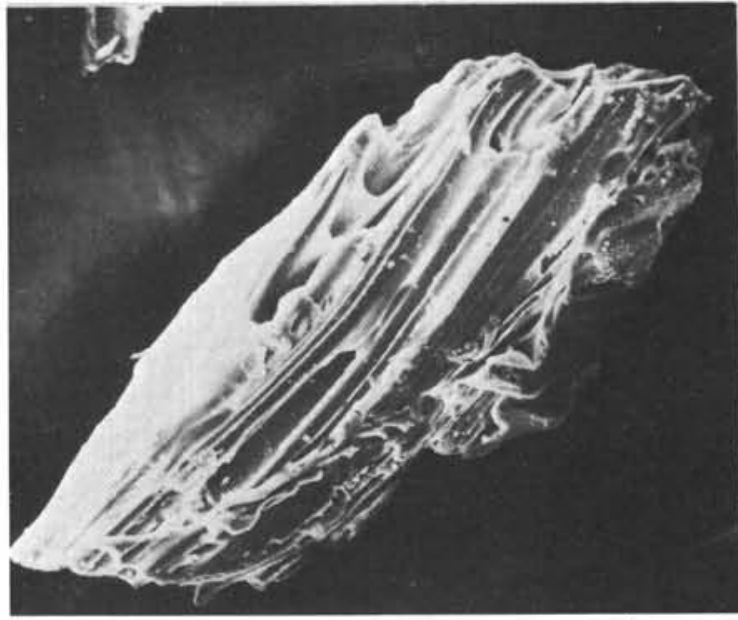

1
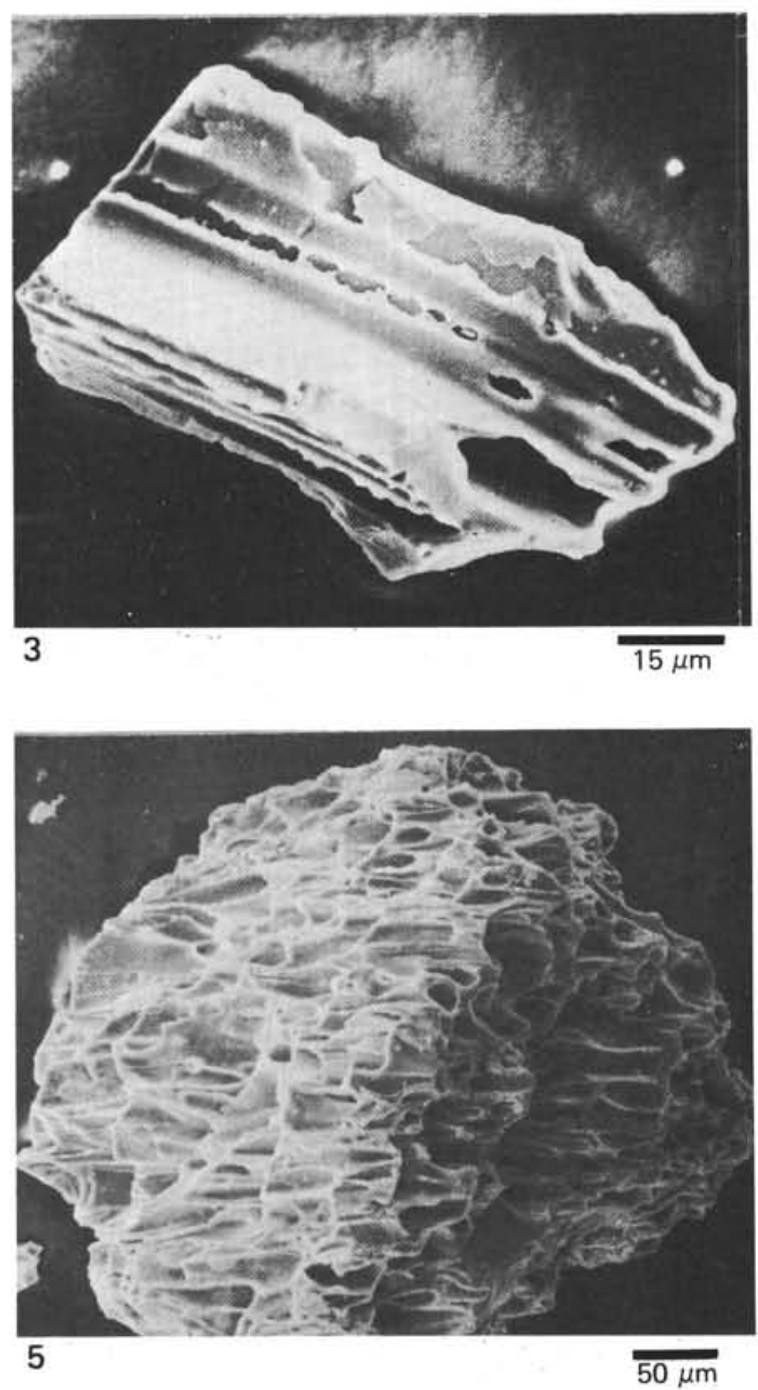

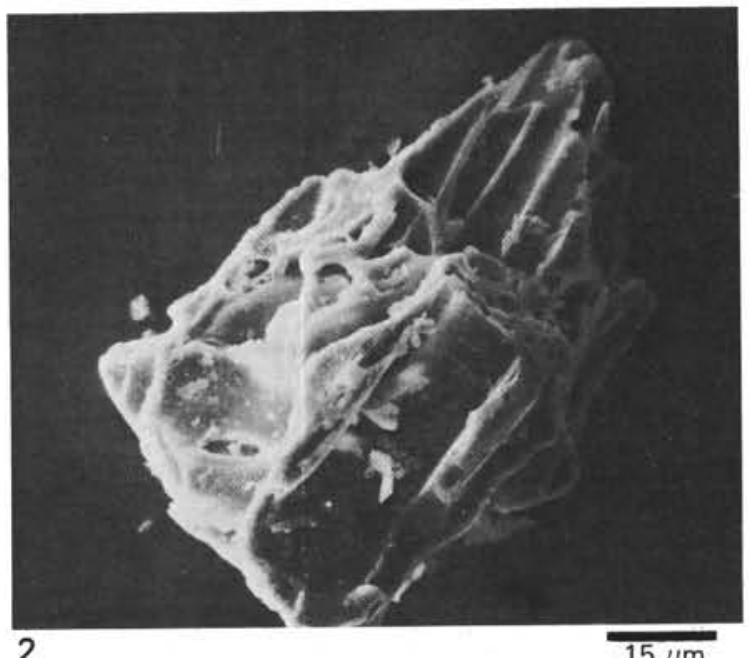

2

$15 \mu \mathrm{m}$
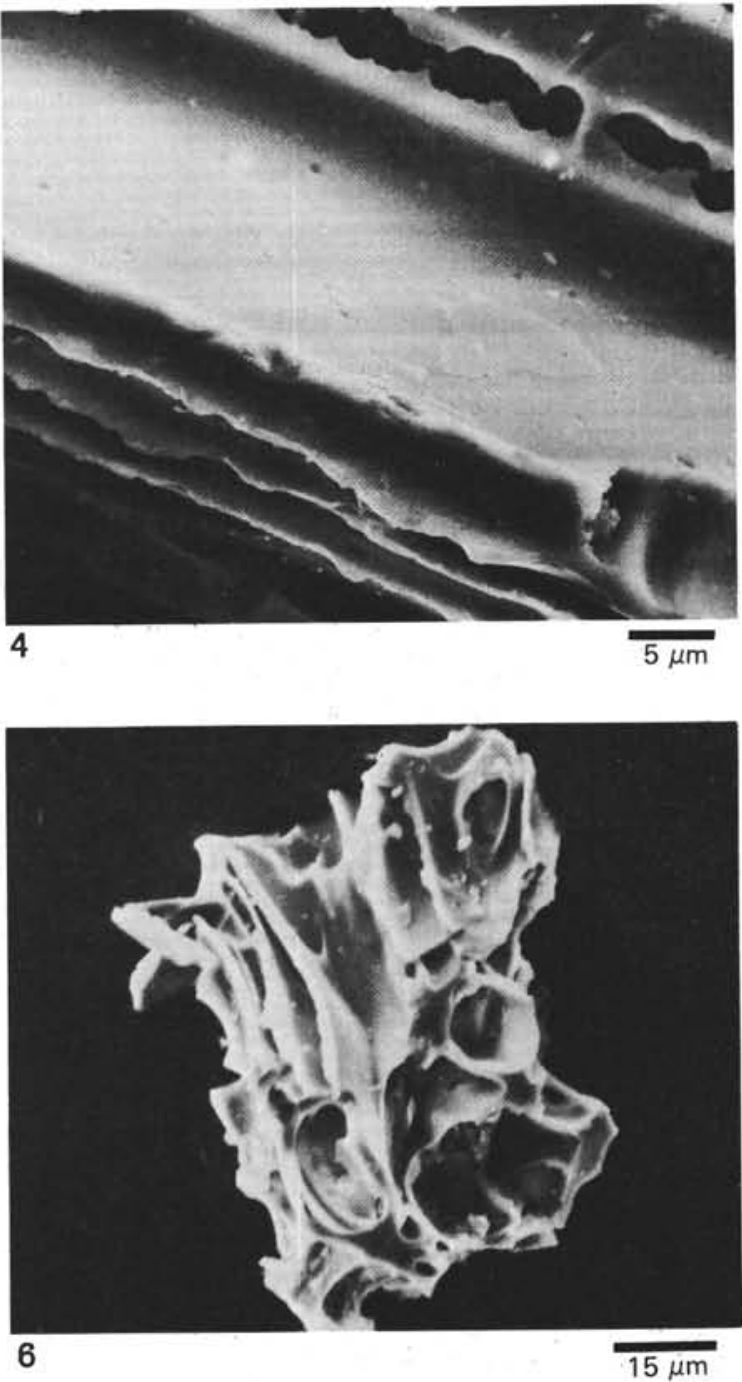

Plate 2. Scanning electron microscope photographs of volcanic glasses. 1. Elongate glass shard with tubular and parallel vesicles. $\times 400$. Sample $494 \mathrm{~A}-17-2,118 \mathrm{~cm}$. Upper Pliocene. 2. A slightly flattened glass with tubular vesicles. $\times 800$. Sample $497-2-5,66 \mathrm{~cm}$. Quaternary. 3. Elongated and relatively flattened glass; the broken vesicle walls are generators of shards. $\times 800$. Sample $497-42-7,45 \mathrm{~cm}$. Lower Pliocene. 4. Detail with high magnification $(\times 2000)$ of Figure 3 -angular fragments on the surface are loosely adhering, fine ash fragments. 5. An equant colorless pumice fragment with a lot of pipe vesicles. $\times 200$. Sample 497-36-7, $3 \mathrm{~cm}$. Lower Pliocene. 6 . Micropumice fragment with spherical and podlike vesicles. $\times 800$. Sample $496-5-2,48 \mathrm{~cm}$. Quaternary. 